\title{
O BRASIL DIVIDIDO E A REDE URBANA FRACIONADA
}

Ralfo Matos

\section{1- INTRODUÇÃO}

Para alguns estudiosos, a chamada Globalização tende a homogeneizar economias nacionais, reduzindo distâncias, eliminando diferenças entre regiões e lugares, diminuindo a esfera de atuação dos estados nacionais, submetendo enfim todas as nações aos ditames impostos pela dinâmica da economia mundial. Ainda que haja boa dose de verdade nessas afirmativas, faltam muito mais estudos de aprofundamento para fazer valer essa nova "macro determinação". Falta considerar devidamente o papel de países dotados de diversidade demográfica, cultural e econômica, como o Brasil, onde alguns atributos que lhe são inerentes podem ser capazes de gerar alternativas de desenvolvimento não disponíveis à maioria dos demais países. O próprio tamanho justifica a promoção de esforços visando a ampliação do entendimento das características históricas mais recorrentes, sem perder de vista as velhas iniquidades de difícil erradicação.

Nesse sentido, pensar o Brasil dividido em diferentes espaços subnacionais é uma necessidade que a pergunta sobre quem somos e para onde vamos nos coloca. De outra parte, a pesquisa e o planejamento estão a exigir tratamentos diferenciados que respeitem idiossincrasias e características regionais mais profundas. Continua sendo imprescindível refletir sobre formas atuais de manifestação das desigualdades socioespaciais, com vistas ao estabelecimento de políticas públicas diferenciadas regionalmente, indicando, inclusive, quais os instrumentos mais adequados para mitigá-las.

\section{2- ALGUMAS VISÕES RELATIVAS AO BRASIL DIVIDIDO}

É provável que uma das construções pioneiras mais bem elaboradas que expôs os contrastes entre o Brasil litorâneo e o Brasil interiorano tenha sido feita por Euclides da Cunha, em seu clássico Os Sertões. A oposição entre duas imagens, uma moderna e progressista na franja litorânea e uma outra tradicional e atrasada no grande interior sertanejo, encontra-se presente em vários capítulos do livro. Curiosamente, à medida que a obra tornou-se mais conhecida, surgiam perplexidades e aumentava a consciência nacional Cadernos do Leste 
sobre as impressionantes diferenças que separavam brasileiros em termos de crenças, modos de vida, formas de organização social, diferenças estas que resultaram em uma conflagração das mais desiguais de que se tem noticia.

Um outro estudo pioneiro que se tornou clássico nas Ciências Sociais, exatamente por explicitar claramente o caráter do Brasil dividido, foi o do sociólogo e geógrafo Jacques Lambert. Sua obra, intitulada "Os dois Brasis", editada originalmente na primeira metade dos anos 50, iria constituir-se em marco fundamental no ideário desenvolvimentista e de planejamento econômico e social do país por muito tempo.

Ao analisar o que denominava "a sociedade dualista e o contraste da estrutura social entre os dois Brasis", o autor verificava a existência de duas sociedades distintas, uma que se consolidava em São Paulo e estados do sul, "muito mais móvel e evoluída", outra arcaica e subdesenvolvida no resto do Brasil. Um Brasil novo e um Brasil antigo confrontavam-se, não obstante as numerosas subculturas existentes.

"Os brasileiros estão divididos em dois sistemas de organização econômica e social, diferentes nos níveis como nos métodos de vida ...diferença, grandemente acentuada, entre país novo, próspero e em constante transformação e sociedade velha, miserável e imóvel (...) No Brasil (...) seria fácil encontrar aspectos que lembram os de Los Ângeles ou Chicago e outros que, sem serem tão trágicos, pois no Brasil há lugar para todos, fazem lembrar os da Índia ou do Egito" (...) "É sobretudo nas cidades do Sul que a sociedade brasileira se moderniza ao mesmo tempo que se diversifica; no Rio e em São Paulo e em várias outras cidades menores, a velha aristocracia rural, que ainda predomina em certas regiões do interior, já não constitui mais do que um círculo mundano, que pode ainda conservar alguma influência política em virtude de relações pessoais e familiares, mas que não exerce sobre a população urbana qualquer patrocínio direto (LAMBERT, 1967:101-122).

O autor salientava os contrastes dentro de um mesmo país. Por exemplo, no início dos anos 50, nas cidades do Rio de Janeiro ou do Estado de São Paulo, 85\% dos adultos sabiam ler e escrever, mas no Estado de Alagoas apenas 13\%. A diferença de expectativa de vida entre as populações mais evoluídas e as mais atrasadas era de 18 anos. Confrontando os dois Brasis, o autor chega a aludir um dito popular da época, o de que o Estado de São Paulo era como uma locomotiva que puxava dezenove carros vazios (LAMBERT, 1967:107).

Os dois Brasis eram diferentes sobretudo do ponto de vista econômico. O "desenvolvimento insuficiente" se manifestava, por exemplo, na baixa renda per capita dos brasileiros. Em 1953 estimava-se que a renda média mensal per capita do brasileiro fosse de NCr\$6,46, enquanto no Piaú esse valor não ultrapassava os NCr\$1,59 e no Ceará 
NCr\$2,30. Entretanto, na parte do Brasil que o autor considerava evoluída essa renda era de NCr\$11,91 em São Paulo e quase NCr\$20,00 no Distrito Federal.

"A diferença entre os extremos era da mesma ordem de grandeza que a existente entre o Egito e a Grã-Bretanha (...) a economia dualista já estabeleceu uma grande distância social e econômica entre o Sul e o resto do Brasil (...) Se o Brasil desenvolvido cresce todos os anos em detrimento do Brasil subdesenvolvido, é mais em virtude da extensão do desenvolvimento a outros territórios (...) Essa extensão é relativamente fácil quando se trata de territórios novos do Oeste do Brasil, e bem mais difícil quando se trata do velho Brasil, do Centro Atlântico ou do Nordeste" (LAMBERT, 1967:193/4).

O Brasil para Lambert era um país agrícola e subdesenvolvido. À época em que a industrialização constituía a grande meta de superação do subdesenvolvimento, o autor sublinhava o atraso do país observando que para cada homem ocupado na indústria havia cinco na agricultura, enquanto na Argentina essa proporção era de meio a meio.

Entretanto, já impressionado com a rapidez da expansão industrial após 1930, assinalava a necessidade de se vencer o obstáculo dos transportes difíceis e da energia cara. Lambert via condições favoráveis ao desenvolvimento industrial do Brasil, por causa de suas grandes riquezas naturais, recursos minerais, mercado de que já dispunha - em face da numerosa população - não obstante a necessidade de "investimentos em face da escassez de capitais (locais)". É interessante observar que o autor, àquela época já entendia que o "Brasil é mais um país desigualmente desenvolvido do que subdesenvolvido", que não obstante o fato de ser essencialmente agrícola, "em certas regiões já deixara de ser subdesenvolvido" (LAMBERT, 1967:1893) ${ }^{1}$.

A ideia do Brasil dividido, portanto, não é nova e associa-se às desigualdades espaciais de caráter econômico e social que se reproduzem no país há muito tempo. ${ }^{2}$ Em meados do século XX estas desigualdades evidenciavam-se pelos contrastes entre áreas urbanas e rurais, porções capitalizadas e não-capitalizadas, espaços de latifúndio ou minifúndio, regiões ricas e regiões estagnadas.

Após a obra de Lambert, a ideia do Brasil dual nunca deixou de ser mencionada. Por exemplo, Edmar Bacha por meio do neologismo 'Belíndia', também veiculado por Mário Henrique Simonsem, salientava o fato de que em uma parte do País a população

\footnotetext{
${ }^{1}$ No entanto, o Brasil urbano e o Brasil rural, ou os Brasis do sul e do Nordeste, mesmo com seus domínios próprios, se encontravam indissoluvelmente ligados. "No Nordeste existem centros, relativamente pouco numerosos, em que a nova civilização industrial se impôs vigorosamente; o Sul está cheio de localidades em que ainda não penetram as atividades modernas ... a poucos quilômetros dos arranha-céus do Rio de Janeiro, .... muito perto da cidade cogumelo de Belo Horizonte, existem fazendas abandonadas; comunidades fechadas em que se perpetuam os modos de vida de outrora" (LAMBERT, 1967:103).

${ }^{2} \mathrm{Na}$ verdade, desde o séc. XIX observadores estrangeiros (como o francês Ferdinand Dénis em seu "Resumo da História Literária do Brasil"), impressionados com a existência da escravidão no Brasil, já mencionavam o grande fosso que separava a elite dirigente, rica e instruída, da população escrava, pobre e excluída de qualquer benefício e proteção institucional.
}

Cadernos do Leste

Artigos Cientificos

Belo Horizonte, Edição Especial, 2000 a 2008 
vivia em condições de países ricos, como a Bélgica, e em uma outra, bem maior, sobrevivia na pobreza e miséria, o que fazia lembrar o caso da Índia. Poucos estados do país situados no Sudeste eram economicamente desenvolvidos, dinâmicos e competitivos, enquanto a maioria dos demais era pobre e subdesenvolvida.

Mas se o país mudou tanto nos últimos 50 anos, tais caracterizações continuam válidas? Ou o Brasil dividido ganhou mais complexidade não obstante a persistência das desigualdades sociais?

É indiscutível que mudanças importantes acumularam-se desde os anos de 1950, abrangendo a urbanização, o crescimento demográfico, as migrações de tipo campo-cidade, a industrialização, o mercado de trabalho, os ciclos de crescimento econômico e a maior inserção do país na economia internacional, como mostram MARTINE et al (1990), SANTOS (1993), FAISSOL (1994), FARIA (1976), CANO (1985), CORRÊA (1997a, 1997b), MATOS e BAENINGER (2001), entre outros.

A expansão da infraestrutura econômica, a modernização industrial, a ocupação do Centro Oeste após a construção de Brasília, a mecanização da agricultura e a ocupação de novas fronteiras de recursos, introduziram mais dinamismo ao país a partir dos anos 60 .

Com isso, a urbanização avançou como nunca e a incipiente rede urbana passou a experimentar uma expansão consistente com o surgimento de novas cidades e a consolidação de centros intermediários de expressão, estruturando, por assim dizer, o arcabouço territorial que permitiria a interiorização do desenvolvimento e a desconcentração espacial da população.

A simples observação da evolução do grau de urbanização no País entre 1940 e 2000 deixa claro como foram intensas tais mudanças. Em 1940 apenas 31,2\% da população residia em domicílios urbanos. Em 1960 esse número atingiu os 44,7\%. Vinte anos mais tarde, em 1980, o grau de urbanização chegou a 67,6\%. No ano 2000, de acordo com os resultados preliminares do Censo Demográfico, $81,2 \%$ da população brasileira residia em áreas urbanas. Dessa forma, não surpreende a constatação de que, em 1970, os municípios com população superior a 100 mil habitantes não ultrapassavam a 70, enquanto em 1991, apenas 21 anos depois, esse número evoluiu para 185.

A par dessas mudanças caberia ainda visualizar o país como um conjunto bipartido?

Em trabalho que já se tornou clássico, o Prof. Clélio C. Diniz ao discutir o processo recente de desenvolvimento industrial e desconcentração econômica reforça essa dualidade ao afirmar que o Brasil verdadeiramente dinâmico está restrito a um 'polígono' que abrange o Sul e parte do Sudeste brasileiro, se estendendo de Belo Horizonte a Porto Cadernos do Leste Artigos Cientificos 
Alegre, ficando de fora o Rio de Janeiro e a maior parte do território brasileiro (ver Fig. 1). Nesse espaço,

"um número limitado de novos pólos de crescimento ou regiões têm capturado a maior parte das novas atividades econômicas, cujo resultado está longe de ser uma verdadeira desconcentração, especialmente porque os novos centros estão no próprio Estado de São Paulo ou relativamente próximos dele" ... "o efeito combinado de mudanças nas economias de aglomeração, crescente integração do mercado nacional, relativa disponibilidade de recursos naturais, conflitantes esforços entre os níveis federal e estadual para o desenvolvimento regional, desigualdade regional do gasto em pesquisa, mercado de trabalho profissional e renda tendem a confinar o crescimento econômico nacional na região 'formada pelo' polígono Belo Horizonte-Uberlândia-Londrina/Maringá-Porto AlegreFlorianópolis-São José dos Campos-Belo Horizonte” (DINIZ, 1993:35,58).

A ênfase de sua análise sobre a trajetória recente da indústria brasileira, especialmente nos setores de alta tecnologia do sul e sudeste, vis-à-vis as políticas e investimentos do Estado, dão azos à suas conclusões, mas podem também estar indicando apenas o fato de que as áreas de maior participação e densidade econômica restringem-se a um espaço privilegiado, no qual há cerca de 130 anos acumulam-se grandes volumes de população, investimentos em infraestrutura e instalações produtivas.

As conclusões incisivas de DINIZ (1993), entretanto, causam certa inquietação por introduzirem a ideia de que ao resto do país resta pouca coisa a fazer diante dos efeitos cumulativos do desenvolvimento do core paulista. Contudo, o autor não trabalha com uma temporalidade prospectiva de longa duração e, assim, não vislumbra outras possibilidades de desenvolvimento econômico para o resto do país fora do padrão técnico-moderno que as sociedades de consumo dos países desenvolvidos prefiguram, e que, evidentemente, se encontra presente nos grandes centros urbanos do país.

Algumas manifestações de expansão econômica e demográfica já se desenham no Brasil, embora não vinculadas aos setores de alta tecnologia sediados em grandes metrópoles, mas articuladas a outras facetas da indústria e dos serviços que se orientam por recursos naturais, alguns deles pretéritos e duráveis (por evocarem amenidades que se reportam a aspectos climáticos, geomorfológicos, paisagísticos, culturais, etc), e que, em alguma medida, complementam, inclusive o padrão econômico produtivo já instalado no Sudeste. ${ }^{3}$

\footnotetext{
${ }^{3} \mathrm{Na}$ verdade, esta é uma questão ainda muito controversa. O autor embora negue a continuidade do processo de desconcentração econômica após a década de 1970 admite que " as indústrias orientadas por recursos (metalurgia, cimento, fertilizantes, agroindústrias) ainda dispõem de peso significativo e, inclusive, boa parte do crescimento industrial do País, nos milagres econômicos das décadas dos 50 e dos 70, se fez através delas (estima-se que as mesmas ainda participam com mais de um terço da produção industrial do País)". Contudo, para o autor tais segmentos tendem a perder importância relativa, à medida que a estrutura produtiva vá mudando. Aqui, pode-se perguntar se a especialização nos setores industriais orientados por recursos, como o caso mineiro e fluminense Cadernos do Leste

Artigos Cientificos

Belo Horizonte, Edição Especial, 2000 a 2008
} 
De qualquer maneira, a persistência da dualidade moderno x atrasado, dinâmico x estagnado ou ricos e pobres, continua sendo enfatizada por vários analistas até hoje. Os dados do Censo 2000 não chegam a contrariar a presença dos dois brasis, mesmo com as melhoras nos indicadores de escolarização, saúde e saneamento. Como o nível de concentração de renda não deixou de crescer, a estagnação econômica, o desemprego e a precarização do trabalho continuam em alta, a porção Índia estaria expandindo-se mais rapidamente que a porção Bélgica ${ }^{4}$.

No âmbito da geopolítica internacional, a globalização vem aprofundando essa dicotomia, ao disseminar a exclusão por grandes áreas do Mundo atual, áreas instáveis política e economicamente, crescentemente confrontadas com regiões dinâmicas e estruturalmente desenvolvidas situadas em países da Europa e América do Norte.

Dados do Banco Mundial mostram que o Brasil situa-se na 4a pior distribuição de renda do mundo, sendo que apenas $10 \%$ da população concentram perto de $50 \%$ da renda gerada. Contudo, por estas estatísticas pode-se visualizar mais de dois contingentes populacionais dicotomizando a distribuição de renda, já que além de um segundo grupo ${ }^{5}$, em posição intermediária, há um terceiro grupo integrado por pobres e miseráveis que alcançaria quase a metade da população (cerca de 85 milhões de pessoas) e acumularia apenas $13,5 \%$ da renda total.

Desta forma, mesmo que os números absolutos sobre a pobreza brasileira sejam impressionantes, é provável que a imagem da Belíndia não sirva mais para caracterizar o Brasil das duas últimas décadas. Há mudanças em curso não negligenciáveis, algumas delas reveladas por indicadores internacionais a exemplo do Índice de Desenvolvimento Humano das Nações Unidas. Por esses dados pode-se apontar a existência no país de áreas economicamente dinâmicas, como as existentes nos países desenvolvidos, tais como: i) os

(petróleo), esgotou suas possibilidades em termos de inovação técnica, mesmo que sediada em posição complementar ao parque industrial paulista. Convém observar, inclusive, o poder de fogo que tais segmentos já demonstraram no comércio exterior, o que lhes confere dinamismo e razoável independência.

${ }^{4}$ Do ponto de vista mais antropológico cabe citar o trabalho publicado em 1995 de Darcy Ribeiro, no qual o Brasil dividido passa pela dimensão histórica, étnica e geográfica, como se várias ilhas-Brasil viessem constituindo núcleos de gestação étnica desde o século XVI a partir das contribuições das matrizes portuguesa, negra e índia, cujo fruto, não obstante as desigualdades, é a unidade sociocultural básica de todos os brasileiros. Dessa forma, pode-se localizar a presença de pelo menos cinco Brasis: 1) o Brasil Criolo, de cultura sincrética, resultante da economia açucareira, a partir da fusão racial de brancos, índios e negros; 2) o Brasil Cabloco, típico da bacia amazônica, com populações mestiças (branco e índio) adaptadas à floresta tropical e com fortes heranças da cultura indígena; 3) o Brasil Sertanejo, originário da interiorização baseada na criação de gado, cujo fenótipo típico deriva dos povos indígenas dos sertões nordestinos; 4) o Brasil Caipira, originário dos núcleos paulistas de apresamento de índios do século XVI, cuja população é mestiça, dispersa, desarticulada e culturalmente vinculada às antigas áreas de mineração do CentroSul do país; 5) o Brasil Sulino, no qual mesclam-se antigos gaúchos (dos campos da fronteira rio-pratense), os matutos (lavradores da faixa litorânea do Paraná de origem açoriana) e os muitos descendentes de imigrantes europeus que aqui aportaram nos séculos XIX e XX. (RIBEIRO, 1995)

${ }^{5} \mathrm{O}$ segundo grupo seria formado por algo em torno de 67,6 milhões de pessoas e responderia por $40 \%$ da renda gerada.

Cadernos do Leste

Artigos Cientificos

Belo Horizonte, Edição Especial, 2000 a 2008 
estados do Rio Grande do Sul, Paraná, Santa Catarina, São Paulo, Rio de Janeiro, Espírito Santo, Mato Grosso do Sul e Distrito Federal (coincidindo em parte mas ultrapassando em muito o polígono de desenvolvimento do Prof. Clélio C. Diniz); ii) um outro Brasil convivendo com níveis de pobreza similar aos de países pobres e periféricos $33 \%$ da população); e iii) um terceiro, situado entre os ricos e os pobres, o chamado Brasil Bulgária, aquele que aglutina cerca de $17 \%$ da população de áreas do oeste e norte, a exemplo dos estados de Goiás, Minas Gerais, Mato Grosso, Rondônia, Roraima e Amapá.

É evidente que há simplificações e insuficiências em qualquer tentativa de classificação genérica. ${ }^{6} \mathrm{O}$ país vem se tornando mais heterogêneo em diversos aspectos. A Profa Maria da Conceição Tavares, ao procurar uma síntese tripartite do Brasil atual observa que o mundo do trabalho vem diminuindo, e pode ser conformado: a) pelos que vivem no desemprego disfarçado (40\% da população ativa); b) pelos assalariados mal pagos $(50 \%)$; c) e pelos poucos (10\% restantes) que têm mobilidade social ascendente. Dada a situação de crise geral do emprego, reduz-se sobremaneira a mobilidade social ascendente, enquanto a mobilidade descendente atinge a classe média. Com a pobreza tornando-se cada vez mais heterogênea socialmente, ela passa a abranger várias gerações e inserções socioeconômicas e espaciais diversificadas, fazendo, inclusive, aumentar a separação entre os pobres e os indigentes.

O economista do IPEA Ricardo P. Barros, especialista em pobreza e desigualdade, nos mostra um quadro ligeiramente distinto do apresentado acima. Observa que a mobilidade ascendente não é pequena no país, embora não seja fácil de ser medida. A sociedade brasileira ainda é bastante móvel, contrastando por exemplo, com as sociedades europeias, muito mais rígidas. Não são poucos os casos em que trabalhadores por conta própria acabam bem sucedidos. De outra parte, o pobre brasileiro "não é o trabalhador de baixo salário no setor formal, esse pessoal é de classe média ${ }^{7}$... Os mais pobres são trabalhadores de meia idade do setor informal".

$\mathrm{Na}$ atualidade, cerca de $12 \%$ da população brasileira é considerada extremamente pobre, vivendo com menos de $\mathrm{R} \$ 50,00$ de renda individual por mês. O conjunto de pobres, os que detém alguma insuficiência em termos de necessidades básicas e nutricionais (inclusive os extremamente pobres) chegam a $1 / 3$ da população brasileira.

\footnotetext{
${ }^{6}$ Insuficiências que dizem respeito a inserção de estados em uma classe e não em outra, insuficiências que reportamse ao fato de existirem expressivos bolsões de pobreza mesmo nas áreas mais desenvolvidas do país.

${ }^{7}$ Nesse sentido, Ricardo Barros observa com correção que o que se gasta no Brasil para combater a pobreza acaba se revertendo para as classes médias, por se restringirem aos setores formais da economia, o que resulta em uma redistribuição de renda da classe média para a classe média (ISTOÉ/1705-5/6/2002).

Cadernos do Leste

Artigos Cientificos

Belo Horizonte, Edição Especial, 2000 a 2008
} 
Dados do Censo 2000 mostram que 12,7 milhões de chefes de família estavam abaixo da linha de pobreza. O número absoluto é maior do que os 11,7 milhões de 1991, mas em termos relativos os 'pobres' representam, em 2000, 28,4\% do total de chefes de família, uma queda de 4,9 pontos percentuais em relação a 1991. Abaixo da linha de pobreza situavam-se os chefes de família que ganhavam 1,46 s.m. em 1991 e 1,47 s.m. em 2000. (Folha de S. Paulo 8/5/2002). ${ }^{8}$

Em face dessas discussões e das controvérsias que percorrem o debate é útil apropriar-se de algumas contribuições procedentes da Geografia que introduzem outras formas de ver o Brasil dividido, já que essa disciplina sempre trabalhou com a organização do espaço, detendo-se, particularmente, na vida de relações que definem estruturas socioambientais e econômico-demográficas.

\section{3- AS DIVISÕES DO BRASIL VISTAS PELA GEOGRAFIA}

Inicialmente convém salientar que as divisões que a Geografia oferece à reflexão e uso operacional não são necessariamente exclusivas ou excludentes umas às outras, frequentemente são complementares. Pode-se, inclusive, conviver com distintas divisões funcionais do país, sem a necessidade de se ter uma única e definitiva, desde que cada uma delas expresse significados ricos e úteis aos diferentes níveis em que se dê a análise, digamos, em sua acepção mais socioespacial.

$\mathrm{Na}$ verdade, a Geografia possui uma longa trajetória de debates acerca de divisões em seu próprio interior, seja pela ênfase nas abordagens mais associadas ao meio físico, seja pelos estudos baseados em fenômenos dinâmicos que se reportam à cultura e sociedade. Dessa forma, as divisões do espaço deram origem a metodologias que privilegiavam a ideia de homogeneidade, complexidade ou heterogeneidade. ${ }^{9}$

De qualquer forma, constitui uma prerrogativa claramente discernível na Geografia, o fato de o espaço poder ser expresso concretamente por pontos, linhas e volumes, traduzindo conjuntos de lugares não só caracterizados por latitudes e longitudes, mas também por ambientes urbanos e rurais, agrícolas e industriais, dentro de uma dada estrutura demográfica, econômica e social.

\footnotetext{
${ }^{8}$ Os dados sugerem que a pobreza tem aumentado mais rapidamente nos maiores centros urbanos. Na década, a proporção dos sem renda nas cidades com mais de 300 habitantes saltou de 2,5\% para 9,2\%.

${ }^{9}$ Durante muito tempo as discussões entre estas concepções foram calorosas e recorrentes, sem contudo chegarem a um consenso. Até hoje a conceituação de região guarda certa imprecisão, maior ou menor conforme o país. Juillard, por exemplo, imaginou a França dividida em oito regiões com raios em torno de $125 \mathrm{Km}$, população 3 a 10 vezes à

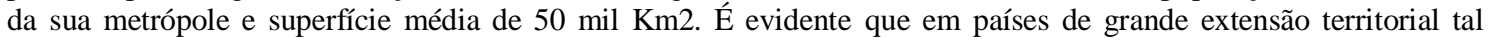
definição poderia alterar-se bastante. Na mesma França, Boudeville (também geógrafo) entendia que uma região deveria ter de 30 a 40 mil Km2.
}

Cadernos do Leste

Artigos Cientificos

Belo Horizonte, Edição Especial, 2000 a 2008 
A busca de um gabarito para se dividir o espaço nacional em recortes regionais depende muito dos critérios do planejamento em determinado momento, e de fatores físicos, históricos, entre outros. Esta contingência acabou por fazer avançar a pesquisa e as redefinições neste campo de estudo, estimulando a transdisciplinaridade à medida em que ampliavam-se as disparidades regionais. Tornava-se urgente aumentar os efeitos propulsores das áreas mais dinâmicas sobre suas periferias, e isso requeria a cooperação de diferentes áreas do conhecimento. A diversidade da Geografia e seus instrumentos técnicos e analíticos sem dúvida favorecem-na nesse debate.

No Brasil especificamente, pode-se enumerar várias propostas baseadas em grandes divisões regionais. A título de ilustração, pode-se registrar, até mais ou menos 1940, as seguintes divisões: de 1889 do engenheiro André Rebouças com a estratificação do país em 10 subespaços; a do geógrafo Elisée Réclus, de 1893, cuja proposta pensava o país em oito regiões; a de 1913, do Professor Delgado de Carvalho com a ideia do Brasil dividido em cinco grandes recortes (proposta que se mostrou vencedora com o passar do tempo); a de 1927, de Piere Denis, com uma divisão em seis regiões; a de 1937, de Betim Paes Leme, com sete grandes regiões; a de 1939, de Moacir Silva com uma divisão em oito regiões; e as de Ezequiel de Souza Britto e do próprio IBGE, em 1940, com divisões em seis e cinco regiões respectivamente. ${ }^{10}$

\section{4- CINCO, QUATRO OU TRÊS BRASIS?}

Conquanto a regionalização político-administrativa do Brasil seja uma herança do século XIX, após a fundação do IBGE, em 1936, a necessidade de uma definição oficial se tornou mais urgente. Dentre as várias propostas de divisão regional, a de 1913, do Prof. Delgado de Carvalho, tornou-se o modelo preferido pelo IBGE sendo adotada, com algumas modificações em 1942. O geógrafo Fábio Macedo Guimarães foi o responsável pela elaboração de uma divisão oficial do País em cinco 'grandes regiões' naturais, levandose em conta a geologia, o relevo, o clima e a vegetação. Várias foram suas dificuldades, além do problema de colocar cada Unidade da Federação dentro de uma região.

Essa divisão em Grandes Regiões foi redefinida em 1969. As regiões Norte e Centro Oeste mantiveram-se sem alterações. O Nordeste, na nova divisão, reunia as porções ocidental e oriental do Nordeste da proposta de 1942, mais os estados da Bahia e Sergipe, anteriormente pertencentes ao Leste. O Sul diminuiu, ao perder São Paulo, e o

\footnotetext{
${ }^{10}$ Ver GUIMARÃES, F. "Divisão regional do Brasil”. In: Revista Brasileira de Geografia, Rio de Janeiro, 1941, n. 37.

Cadernos do Leste

Artigos Cientificos

Belo Horizonte, Edição Especial, 2000 a 2008
} 
Leste desapareceu dando lugar ao Sudeste. Com o avanço da industrialização e o processo de integração econômico-espacial mais denso reunindo os estados de São Paulo, Rio de Janeiro, Minas Gerais e Espírito Santo, tornou-se mais adequado criar o Sudeste, como 'sucedâneo' da antiga região Leste. A nova regionalização procurava adaptar-se às mudanças socioespaciais que o país experimentava. Dela derivaram várias outras em diferentes escalas, as mesorregiões, macrorregiões e microrregiões. ${ }^{11}$

Passados mais de trinta anos, pode-se perguntar se esse macro divisão em cinco grandes áreas geográficas continuaria ainda adequada, especialmente após a grande expansão do país em direção ao Centro Oeste e o incremento da polarização exercida pela conurbação de São Paulo?

Milton Santos, em obra recente escrita com M. Laura Silveira, propõe uma divisão do Brasil em quatro grandes áreas a partir de materialidades geográficas associadas às heranças históricas e às modernizações mais contemporâneas. Estas últimas resultantes de inovações de cunho "técnico-científico-informacional" que já se encontram cristalizadas em boa parte do país. (SANTOS e SILVEIRA, 2001:268).

A diferença mais notável de sua proposta com a oficial do IBGE diz respeito a junção do Sudeste com o Sul, de modo a configurar a chamada "região concentrada" (ver Figura 2).

Capitaneada pelo desenvolvimento de São Paulo, essa grande área reuniria os mais intensos fluxos de mercadorias, pessoas, capitais e informações. Nela há maior nível de integração econômica e espacial, e a urbanização, o padrão de consumo das empresas e famílias, a vida comercial e a distribuição da população é mais complexa do que no restante do país.

"Atividades ligadas à globalização que produzem novíssimas formas específicas de terciário superior (...) ligado à finança, à assistência técnica e política e à informação vêm superpor-se às formas anteriores do terciário e testemunham as novas especializações do trabalho nessa região. Esse novo setor de serviços sustenta as novas classes médias que trabalham nos diversos setores financeiros, nas múltiplas ocupações técnicas, nas diversas formas de intermediação, marketing, publicidade etc. (SANTOS e SILVEIRA, 2001:269)".

\footnotetext{
${ }^{11} \mathrm{Na}$ verdade o IBGE estabeleceu várias subdivisões regionais nos últimos 50 anos. Em 1955, segmentou as grandes regiões naturais estabelecendo as zonas fisiográficas, levando-se em conta a ação do homem sob as paisagens e a vida social. Em 1968 criou 361 microrregiões homogêneas, tomando como critérios os domínios ecológicos, a população, as regiões agrícolas, a atividade industrial e terciária e a infra-estrutura de transportes (mantinha-se a homogeneidade do espaço como forma de organização da produção). Um problema comum a ambas divisões foi o do contraste no nível da ocupação do território, o que fez surgir áreas muito grandes e outras muito pequenas. Em 1974, foram criadas as nove regiões metropolitanas, o que levaria o órgão, a partir de então, a promover estudos sobre as áreas polarizadas, com o fito de obter um modelo de Divisão Regional para fins de ação administrativa. Finalmente, em 1990 o IBGE substitui as regiões homogêneas pelas "regiões geográficas", quando a dominância do físico cede lugar a critérios mais abrangentes, associados ao âmbito da Geografia Humana.
}

Cadernos do Leste

Artigos Cientificos

Belo Horizonte, Edição Especial, 2000 a 2008 
A região sobre a influência de São Paulo cresce mais que a grande cidade. Beneficiam-se com isto o interior do Estado e boa parte da região Sul, com a disseminação de capitais fixos, como estradas, silos, depósitos, frigoríficos, telecomunicações, além de maquinários, veículos, sementes, adubos, etc, fazendo multiplicar a importância dos fluxos, especialmente a dos fluxos financeiros. (SANTOS e SILVEIRA, 2001:270-71).

Para os autores, uma segunda grande região se estabelece no Centro Oeste, sendo constituída pelos estados de Mato Grosso do Sul, Mato Grosso, Goiás e Tocantins. Tratase de espaço de ocupação periférica, onde o "meio técnico-científico-informacional se estabelece sobre um território praticamente natural, ou melhor, pré-técnico, onde a vida de relações era rala e precária (...) 'mas hoje sedia' produtos de uma agricultura globalizada soja, milho, algodão, arroz - cultivados numa área que abriga as maiores densidades de mecanização agrícola (um trator para cada 8,8 habitantes agrícolas, uma máquina de colheita para cada 54,7 habitantes), o maior consumo de fertilizantes e defensivos agrícolas e a utilização de tecnologia de ponta, como a agricultura de precisão (...) produção de alimentos que se dá em fazendas modernas dispersas", o que faz surgir "novos objetos e ações em um espaço inteiramente novo”. (SANTOS e SILVEIRA, 2001:271).

A terceira região corresponde ao Nordeste, conforme divisão do IBGE. Para Santos, suas características são basicamente as seguintes: povoamento antigo, mecanização pontual e episódica, agricultura pouco moderna (um trator e uma colheitadeira para, respectivamente, 148 e 1373 habitantes agrícolas), em meio a estruturas fundiárias arcaicas, resultando em uma taxa geral de urbanização baixa e em um quadro socioespacial praticamente engessado. (SANTOS e SILVEIRA, 2001:272). 


\section{Figura 2 \\ Divisões Regionais do Brasil Propostas por Autores da Geografia}

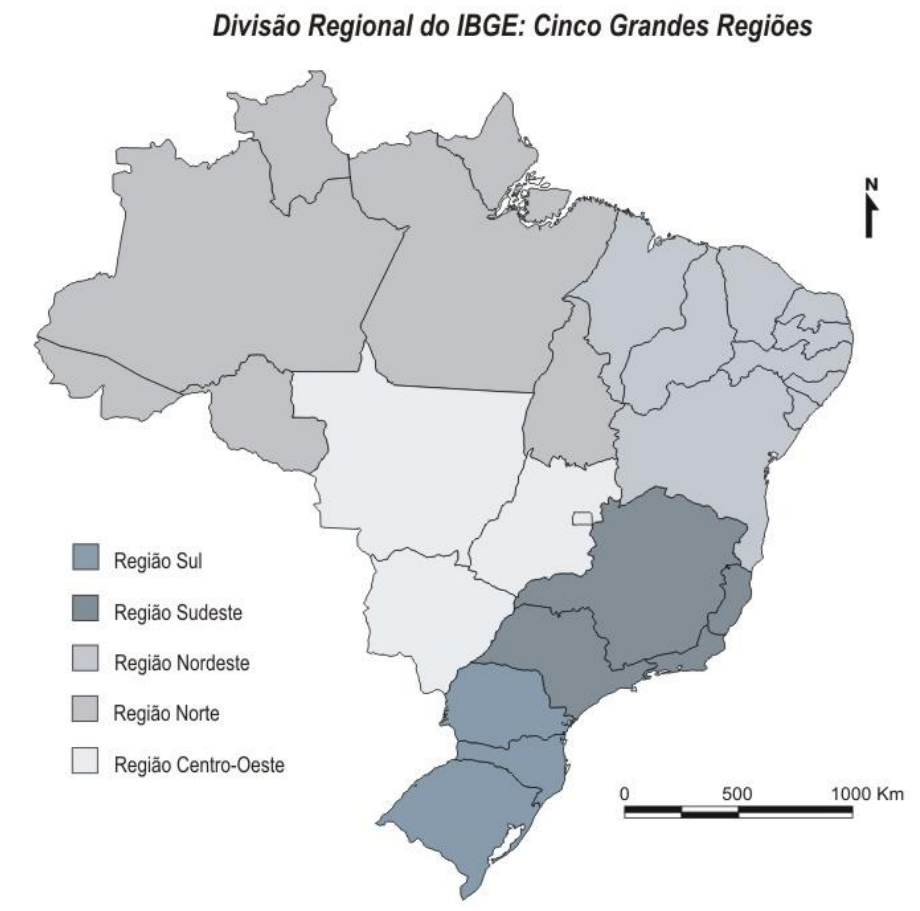

A Regionalização de Milton Santos: Quatro Grandes Regiões

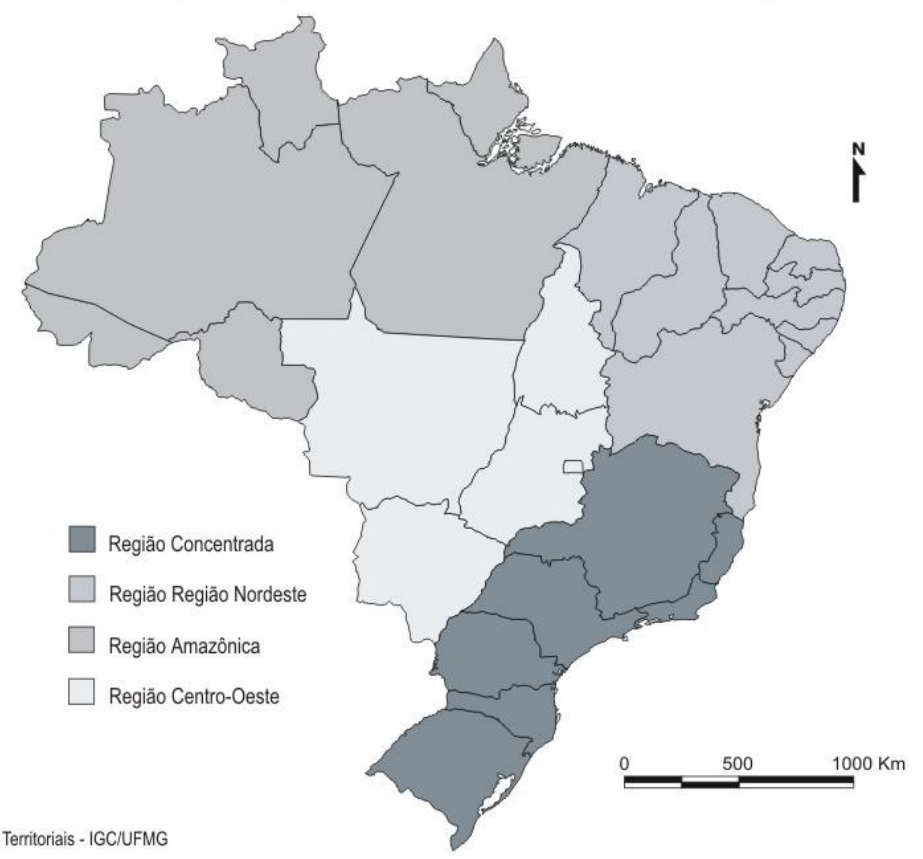

Execuçăo: Laboratório de Estudos Territoriais - IGC/UFMG

A quarta e última região, onde a globalização começa a penetrar, seria definida pelos Estados do Amapá, Pará, Roraima, Amazonas, Acre e Rondônia. Caracteriza-se por baixas densidades demográfica, técnica e de urbanização - a última a ampliar sua mecanização -, com articulações feitas por hidrovias (Madeira-Amazonas) e núcleos Cadernos do Leste Artigos Cientificos 
urbanos multifuncionais que comandam vastas áreas. Manaus, "consolida sua vocação como pólo industrial sob o amparo da regulação especial da Zona Franca, exibindo sistemas de movimento modernos e rápidos e sistemas de movimento lento e tradicionais". (SANTOS e SILVEIRA, 2001:273).

É interessante notar que o que Milton Santos vinha chamando de Região Concentrada, na verdade aproxima-se do polígono de desenvolvimento dinâmico como quer DINIZ (1993). Todavia, amplia-o ao incluir o Rio de Janeiro e o Espírito Santo, estados que econômica e geograficamente estão intensamente articulados às estruturas territoriais do Brasil meridional. Ademais, destaca a forte importância do terciário moderno em sua economia, além, evidentemente, da indústria.

No entanto, a separação do Centro Oeste como periferia da região concentrada parece algo artificial, já que áreas periféricas ao core paulista existem em muitos subespaços no Sul e Sudeste, ambos pertencentes a mesma região concentrada. A bem da verdade, boa parte do Centro Oeste é uma extensão 'natural' da área de influência de São Paulo, denotando a mesma inserção econômica baseada em alta tecnologia, com a diferença apenas no fato de se tratar de um espaço geográfico onde a população é mais rarefeita. Aliás, mesmo no longo prazo, dificilmente a densificação que ocorreu no Sudeste virá prevalecer nessa região dado o seu perfil de ocupação agrofundiária, suas condições naturais e sua localização relativa. Note-se que o próprio Rio Grande do Sul, ou Minas Gerais ainda exibem vastas porções de seu espaço com características semelhantes em termos de mecanização, predomínio agrícola e agroindustrial e baixas densidades demográficas.

Em face dessas observações e dada a relativa insuficiência da proposta de SANTOS e SILVEIRA, cabe introduzir uma requalificação dos espaços físico-territoriais do Centro Oeste, de modo que sua inserção ganhe outra lógica. Nesse caso, é mister: i) abstrair-se dos limites estaduais (aspecto que dificulta a flexibilização das partições macrorregionais), ii) considerar os atributos físicos que aludem à contextos físico-geográficos, notadamente os que se referem a Amazônia e ao que poder-se-ia denominar de geografia das grandes distâncias em "domínios” tropicais não litorâneos. Assim sendo, a solução que parece mais simples é a própria divisão do Centro Oeste em duas fatias uma mais referida a Amazônia e Pré-Amazônia, outra referida a expansão da área "geoeconômica" de São Paulo, e nesse caso surge a divisão do país em três grandes porções. Essa divisão pode resolver parte das dúvidas levantadas acima. E isso já havia sido feito há mais de 30 anos. 
Em fins dos anos 60, provavelmente em decorrência dos prováveis impactos da mudança da Capital para Brasília, o geógrafo Pedro P. Geiger dava visibilidade a uma divisão do país baseada em aspectos geoeconômicos. Geiger mostrava a existência de três grandes complexos regionais, o Centro Sul, com a reunião do Sul, Sudeste e parte do Centro-Oeste, o Nordeste, reunindo um conjunto de estruturas econômicas do passado e a Amazônia, a grande fronteira de recursos ainda a ser explorada. Tal divisão baseava-se, em boa medida, em domínios morfoclimáticos e geoeconômicos. Nesse último, a dimensão do planejamento regional passava a ser incorporada, já que as linhas que delimitavam, por exemplo, a área de atuação da Sudene, de um lado, e a chamada Amazônia Legal (onde atuava a Sudam) foram contempladas em sua proposta (ver Fig. 3).

O Centro Sul aglutinava um grupo de espaços mais diretamente subordinados aos pólos nacionais do Rio de Janeiro e São Paulo. O autor considerava que era a "partir dos núcleos metropolitanos do Sudeste que se realiza a integração, não só a do Centro-Sul, principalmente, como de todo o conjunto nacional, apoiada na industrialização e na extensão da rede de transportes rodoviários". Observava que o Sul era o espaço econômico com "diversas regiões originadas de moderna colonização europeia ou de descendentes destes colonos", onde firmavam-se "forças polarizadoras das metrópoles regionais de Curitiba e Porto Alegre, numa integração superior a das metrópoles nordestinas". A porção Centro Oeste seria uma espécie de periferia "por onde transbordam atualmente populações e empreendimentos agrícolas e urbanos desde o Sudeste e o Sul". Por ela se estenderiam as linhas de penetração terrestre para a Amazônia desde o Centro Sul, linhas estas mais dinâmicas que as desenvolvidas desde o Nordeste. (Geiger, 1969:16/1967).

O Nordeste, por seu turno, em relação ao recorte oficial da Grande Região, perdia parte do Maranhão, mas reunia espaços do norte e nordeste de Minas Gerais (ver Mapa). Concentrava cerca de $1 / 3$ da população brasileira e apresentava traços de coesão histórica e econômica. Nele conviviam regiões tradicionais (como a Zona da Mata pernambucana e o Recôncavo baiano), que não experimentaram "renovações como as verificadas no CentroSul quanto à afluência de novas levas de população proveniente do exterior e processos de industrialização", o que o tornou um espaço "sem economia autossustentada" e bastante subdesenvolvido. "As grandes cidades apresentam seu papel de centros de drenagem, mais do que de irrigação de suas áreas de influência, (...) sem chegar a modificar substancialmente as estruturas tradicionais" e se dividem segundo as sub-regiões polarizadas por Salvador, Recife e Fortaleza. (Geiger, 1969:16).

Cadernos do Leste

Artigos Cientificos

Belo Horizonte, Edição Especial, 2000 a 2008 
A terceira grande região, a Amazônia, correspondia a uma imensa unidade geográfica vazia de população, "constituída por grandes domínios naturais, onde pontos isolados de ocupação humana mantêm ligações tênues, traduzidas principalmente nos fluxos de pequenos volumes de mercadorias. A extrema macrocefalia é representada pela concentração de população em Belém e Manaus". (Geiger, 1969:15).

A chamada divisão geoeconômica, vista com os dados de hoje, se apresenta adequada em vários aspectos (como se mostrará adiante), não obstante as controvérsias que ela suscita. A Amazônia, por exemplo, continua sendo um espaço onde a natureza impõe condicionantes fortes à ocupação humana, o que a torna rarefeita demograficamente, daí a hipertrofia de Manaus e Belém como pólos regionais. 
Figura 3

Proposta de Divisão Regional do Brasil de Pedro Geiger

Os Três Grandes Complexos Geoeconômicos

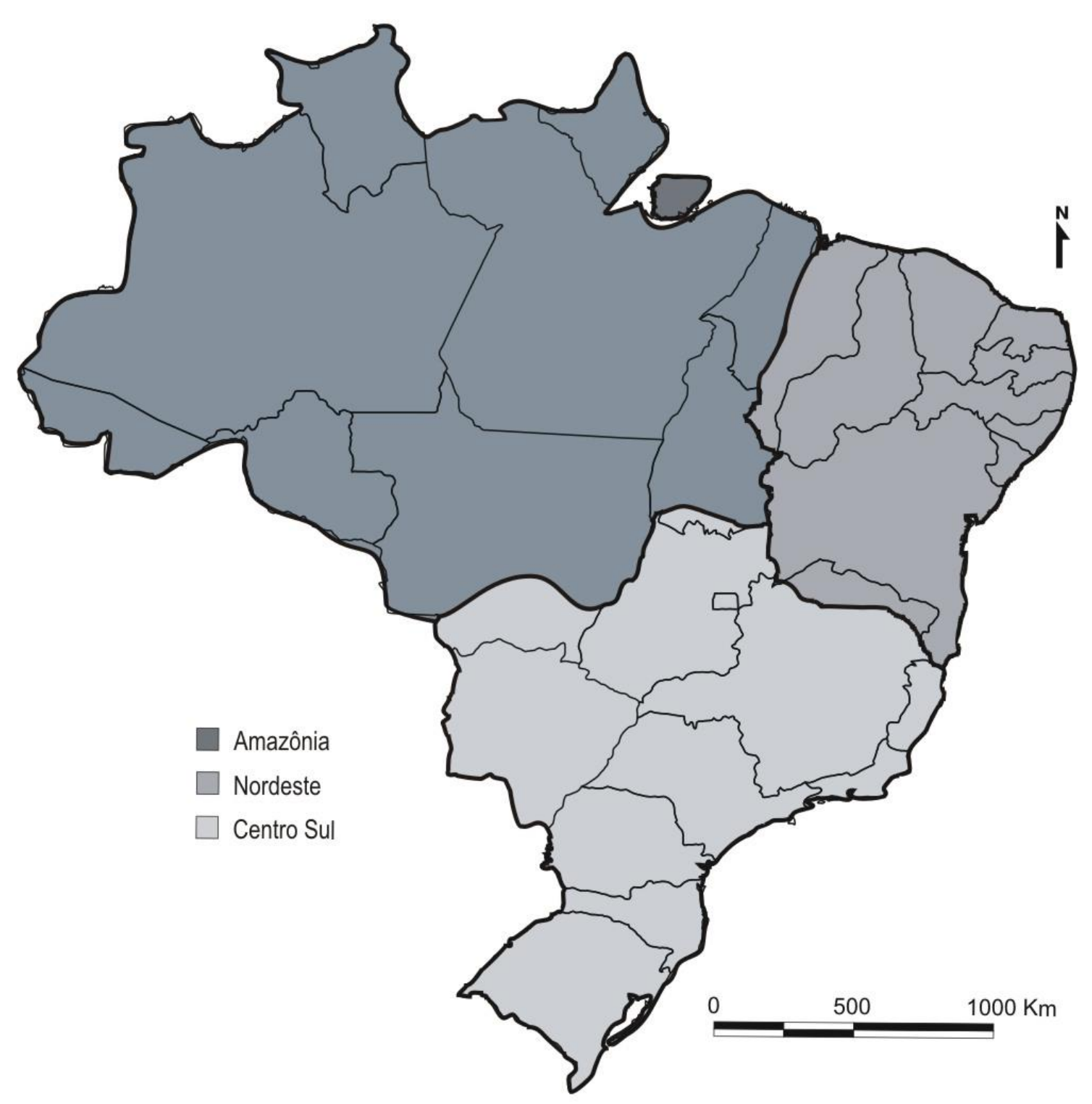

Execuçăo: Laboratório de Estudos Territoriais - IGC/UFMG 
Contudo, o isolamento e a desarticulação da época reduziram-se muito, e isso associa-se aos investimentos estatais em infraestrutura, ao lado do surgimento de novos nichos econômicos na região, como o que delineia o corredor Araguaína-Carajás-Palmas-São LuisBelém. Mesmo o Nordeste, tido como região atrasada e tradicional, vem gradativamente experimentando mudanças em vários de seus subespaços, a favor de um maior dinamismo e diversificação econômica.

Contudo, talvez o principal mérito de Geiger situe-se em sua antevisão quando indicava a integração macrorregional envolvendo o Sudeste e parte do Centro Oeste. O autor assinalava corretamente que os atuais estados de Goiás e Mato Grosso do Sul (por força da expansão paulista), juntamente com a hinterlândia de Brasília-Goiânia tornar-seiam áreas extremamente dinâmicas economicamente.

Nessas alturas, pode-se indagar se é possível ou pertinente por a prova a divisão de Geiger com dados mais recentes?

Os itens em sequência, na verdade, não foram construídos visando responder essa indagação, embora, coincidentemente, utilizando-se de um caminho peculiar bem distinto do de Geiger ${ }^{12}$, tenhamos chegado a um desenho bastante próximo do seu.

Esse caminho, antes de mais nada, passa pela ideia de se examinar os espaços regionais a partir da premissa de suas múltiplas articulações em sistemas e subsistemas. Aqui foi essencial pensar as regiões estruturadas mediante as lógicas que presidem as redes geográficas, notadamente as redes urbanas. Espera-se com isto reforçar a ideia de que a especialidade das redes facilita a análise de relações socioeconômicas dinâmicas, envolvendo fluxos que vinculam localidades. Fluxos capazes, inclusive, de delinear corpos regionais mais ou menos nítidos.

\footnotetext{
${ }^{12}$ Geiger certamente apoiou-se em divisões geográficas muito veiculadas à época dos esforços nos governos militares voltados ao planejamento regional, que procuraram instrumentalizar a Sudene e a Sudam, por exemplo. Assim, a área da Sudene cobria o Nordeste e separava-se do Sudeste por meio do chamado "polígono da seca", a área da Sudam reportava-se à chamada Amazônia Legal, perímetro que separa o Norte, do Nordeste e Sudeste. Por exclusão, pode-se intuir que além dessas linhas demarcatórias sobravam a maior parte dos estados de alta centralidade do Sudeste e Sul, dando origem ao Centro-Sul.
} 


\section{5- REDE URBANA: ESPAÇOS SOCIAIS EM MOVIMENTO}

As redes urbanas tornaram-se importantes na literatura sobretudo com a grande urbanização em muitos países no começo do século XX, o que fez com que o tema passasse a ser objeto de investigação e elaborações teóricas desde pelo menos a década de 1930, com os trabalhos de W. Christaller, Losch, entre outros.

No Brasil, embora não tenham sido muitos os trabalhos analisando a rede urbana, o próprio IBGE já produz estudos de regionalização mediante critérios baseados no avanço da urbanização e das redes de interdependências há bastante tempo. ${ }^{13}$ Mais antigos foram os estudos pioneiros de Pierre Deffontaines e Aroldo Azevedo, além dos trabalhos de MONBEIG (1952, 1954) e GEIGER (1957 e 1963), os quais se detiveram na evolução da rede urbana que se desenhava entre os anos de 1940 e de 1950.

Nos anos de 1970, DAVIDOVICH e LIMA (1975) e DAVIDOVICH e FREDRICH (1976) identificaram no País estruturas urbanas experimentando um intenso processo de expansão, nas quais distinguiram "uma bierarquia de áreas urbanas" em tamanhos e complexidade crescentes. À mesma época, vários trabalhos surgiram ocupando-se da problemática das cidades médias e do planejamento urbano voltado para a descompressão espacial (após o lançamento pelo Governo Federal do Programa de Cidades Médias), a exemplo de FARIA (1976 e 1983), ANDRADE, T.A. e LODDER, C.A. (1986) e FRANCISCONE, J.G. e SOUZA, M.A.A. (1976).

Os anos de 1980 foram de diminuição dos trabalhos nessa área, algo que durou mais de 10 anos. Nos anos de 1990, no entanto, ocorre uma profusão de artigos revitalizando a discussão sobre território e redes, nesse caso, indo além das redes urbanas estrito senso. ${ }^{14}$

Diante desse quadro, resta indagar sobre o que afinal dizem as redes, particularmente as redes urbanas, e como podem auxiliar na construção de um novo olhar para o Brasil de hoje.

As redes podem expressar dimensões abstratas, mas comumente traduzem materialidades espaciais. São espaços e subespaços em movimento. São lugares articulados por fluxos multivariados. Fluxos de pessoas, capitais, informações, ideias e culturas. As redes mais importantes estão carregadas de técnica e história social, sendo portanto

\footnotetext{
${ }^{13}$ São estudos diversos, tais como os publicados em 1972, 1987, 1988, entre outros (ver bibliografia), geralmente derivados da contribuição de Christaller e Brian Berry, que objetivam avaliar a evolução da rede de cidades e a reconfiguração da hierarquia urbana e das respectivas áreas de influência.

${ }^{14} \mathrm{O}$ conceito de redes geográficas revigora-se na atualidade, fazendo parte de um conjunto maior de conceitos básicos da Geografia. Alguns trabalhos sobre o tema dignos de nota: SANTOS (1993), CORDEIRO (1990), CORRÊA (1993, 1997a, 1997b), RANDOLPH (1990), DIAS (1995 e 1996), HAESBAERT (1995) e SOUZA (1995). Cadernos do Leste

Artigos Cientificos

Belo Horizonte, Edição Especial, 2000 a 2008
} 
construções dinâmicas relativamente duráveis. As redes urbanas, por exemplo, são depositárias de estruturas sociais pretéritas e futuras, tradicionais ou modernas, que dão forma e sentido a vida de milhares de pessoas, famílias e instituições.

Castells chega a dizer que as redes estariam a constituir a nova morfologia social de nossas sociedades, e a difusão das lógicas subjacentes à elas influem nos resultados dos processos de produção e na própria noção de poder e cultura. Talvez essas alterações sejam o corolário do fato de as redes serem estruturas abertas altamente dinâmicas, aptas a se expandirem, atuando como instrumentos econômicos, sociais e culturais, como salienta RANDOLPH (1999:43).

Enfim, pode-se concordar com a premissa de que mais importante que a definição de rede sejam os indicativos sobre os tipos de ligações que se apresentam entre os lugares, como propõe o Prof. Roberto L. Corrêa. A rede geográfica, mesmo sendo um conjunto de localizações geográficas interconectadas entre si, pode representar vínculos dados por exemplo, por "uma sede de cooperativa de produtores rurais e as fazendas a ela associadas, como pelas ligações materiais e imateriais que conectam a sede uma grande empresa, seu centro de pesquisa e desenvolvimento, suas fábricas, depósitos e filiais de venda" CORRÊA (1997:107).

\section{6- REDE URBANA E POPULAÇÃO: UMA FORMA SIMPLES DE REPRESENTAÇÃO}

Parte dos princípios básicos das estruturas em rede dizem respeito a existência de funções diferenciadas assumidas pelos componentes da rede. As principais localidades, como preceituava Christaller, "são dotadas de funções centrais, isto é, atividades de distribuição de bens e serviços para uma população externa, residente na região complementar", na hinterlândia. "A centralidade de um núcleo, por outro lado, refere-se ao seu grau de importância a partir de suas funções centrais: maior o número delas, maior a sua região de influência, maior a população (grifo nosso) externa atendida pela localidade central, e maior sua centralidade". CORRÊA (1994:21).

É evidente que os estudos de rede urbana mais detalhados mostram os fluxos de mercadorias entre as localidades, preferentemente classificadas segundo gênero, tipo, peso e valor agregado, de modo a permitir o estabelecimento das hierarquias e as relações de dependência resultantes das funções que cada localidade desempenha.

As redes urbanas podem ser expressas mediante técnicas que combinam um grande número de dados econômicos, sociais e geográficos, preferentemente transcritos em intensidades variáveis de fluxos entre as localidades. Essa intensidade é suscetível de Cadernos do Leste

Artigos Cientificos

Belo Horizonte, Edição Especial, 2000 a 2008 
formalização matemática de modo a gerar níveis hierarquizados de relações dominantes e subordinadas, configurando sistemas e subsistemas espaciais.

O dado populacional está sempre presente nas formulações teóricas e é sempre utilizado em qualquer técnica de regionalização, não raro substituindo variáveis de fluxo inexistentes. Sobre os significados da população enquanto variável-controle, especialmente o das populações em movimento, convém observar que elas não só exprimem a sociedade, a cultura e a ação política, real ou virtual, impactam também os ambientes onde se reproduzem, por constituir força de trabalho e mercados de consumo, fatores chaves para a geração de riqueza. Ademais, o estudo das populações, sobretudo com base em dados censitários, permite conhecer em detalhes várias das características dos fluxos de pessoas entre as localidades, pré-requisito para a formação de redes geográficas e redes sociais.

Assim, pode-se pensar em formas mais simples de se produzir uma rede de lugares urbanos, utilizando-se para isso de três pré-condições. A primeira baseia-se no uso da "variável" população como síntese de relações socioculturais e proxis de tamanho econômico das localidades. A segunda define às localidades geográficas formadoras da rede: espaços urbanos dotados de alta centralidade, nucleados em cidades e representados cartograficamente como pontos ou nódulos. A terceira define o tipo de articulação entre tais localidades: articulações viárias, tais como rodovias, ferrovias e hidrovias. O fundamento aqui reside na capacidade de transportabilidade dessas vias e na sua presença recorrente em clássicos da literatura sobre localização e regionalização. Mesmo nos dias de hoje os custos de transporte são decisivos, espacializam relações econômicas e associam fortemente população, espaço e economia.

Esse exercício de quantificação e mapeamento da evolução recente da rede de cidades do Brasil baseia-se em dados de estoque populacional dos Censos de 1991 e 2000. A ideia é indicar os vetores territoriais de crescimento demográfico como expressão das tendências predominantes na hierarquia urbana brasileira. Propõe-se, com isso, uma forma metodologicamente simples, de representar o formato, a localização e a configuração espacial do que é mais relevante na rede urbana brasileira contemporânea. ${ }^{15}$

Os critérios que orientam a seleção dos pontos (nódulos) da rede de cidades partem do peso populacional das localidades urbanas em seus estados e da existência de articulações viárias entre tais pontos, segundo o recorte físico-territorial de 1991. Tais

\footnotetext{
${ }^{15}$ Cabe observar que esse exercício procura estabelecer um esboço do desenho da rede urbana, passível de ser explorado analiticamente, mediante dados censitários (particularmente os de migração), de acordo com pe squisa que se encontra em andamento. Com isto não se ignora a existência de outras propostas que, inclusive, são metodologicamente mais robustas do que a que é aqui apresentada, embora as concepções teóricas que fundamentam tais propostas sejam distintas. Por outro lado, os resultados aqui alcançados e o próprio desenho da rede coincidem em grande medida com outras formulações recentes disponíveis na literatura..
} 
articulações, representadas por segmentos de reta unindo nódulos, são as mais importantes regionalmente e geralmente indicam a existência de rede de transportes rodoviário ou hidroviário permanente.

As cidades, ou centros urbanos, são tomadas como as áreas urbanas dos municípios, incorporando, portanto, o que os censos do IBGE identificam como 'cidade' e 'vila'. ${ }^{16}$ Para efeito de simplificação e operacionalização na geração de dados demográficos, os municípios comparecem como unidades mínimas de observação. Todavia, podem assumir a forma de aglomerações municipais, no caso das Regiões Metropolitanas (como definidas em 1991). Mais especificamente, os critérios adotados para a seleção dos pontos, ou nódulos, consideram: i) municípios integrantes das Regiões Metropolitanas oficiais (cada região metropolitana comparece, na rede urbana, como um nódulo de primeira ordem); ii) município com população urbana superior a 100 mil habitantes (pontos da rede relativos às chamadas Cidades Médias); iii) município cuja população urbana representasse mais de 3\% da população urbana do respectivo estado; iv) município com população urbana superior a $3 \%$ da população urbana do estado do Amazonas excluindo Manaus (pontos de uma rede dentrítica sem visibilidade diante do tamanho de Manaus).

Com esses dois últimos critérios recobrem-se os contextos espaciais em que há municípios pouco populosos, mas de importância estratégica na rede urbana regional (como nos casos do Norte e Centro Oeste), assim como os muitos municípios populosos, de porte médio, comuns no Sudeste e Sul. ${ }^{17}$

A Tabela 1 apresenta, para 1991, os 165 pontos principais da rede urbana aqui proposta segundo os critérios supracitados. Nesse ano o Censo mostrava que quase 111 milhões de pessoas residiam em áreas urbanas (75,6\%). As 165 localidades principais da rede detinham uma população urbana de 69.744 .799 residentes, o que representava $62,8 \%$ da população urbana do país. Se fossem consideradas somente as áreas correspondentes às cidades esse percentual baixava para 56,7\%. Na verdade, a diferença entre os números relativos às cidades que integram os pontos da rede urbana e as áreas urbanas (contíguas e não contíguas) não é grande. As 165 cidades reuniam uma população de 62.919 .942

\footnotetext{
${ }^{16}$ A definição de cidade é sempre suscetível de discussões em face dos seus vários tipos, tamanhos e características funcionais, além dos critérios internacionalmente adotados. Nesse trabalho, a partir dos dados censitários e da definição (controvertida) de área urbana do IBGE, considerou-se como população da cidade de município não conurbado a população de seu distrito sede. Para os municípios conurbados, como nas regiões metropolitanas, somam-se as populações do município núcleo e a dos distritos sede dos municípios da periferia. Nesse último caso, para efeito de simplificação, considera-se que os distritos do município núcleo se encontram conurbados. A Tabela 1 mostra esses dados

${ }^{17}$ A cartografia privilegiou a produção de mapas onde cada ponto representa ou a sede dos municípios ou cada uma das nove regiões metropolitanas. Desta forma, encontravam-se na rede urbana um total de 165 pontos em 1991, e 194 no ano 2000 se mantidos os critérios. As regiões metropolitanas consideradas correspondiam a São Paulo, Rio de Janeiro, Belo Horizonte, Porto Alegre, Salvador, Recife, Fortaleza, Curitiba e Belém.

Cadernos do Leste

Artigos Cientificos

Belo Horizonte, Edição Especial, 2000 a 2008
} 
habitantes o que representava 90,2\% das áreas urbanas dos municípios dessas localidades centrais. Isto, por si só, justifica o uso das populações urbanas municipais como proxis das populações das cidades da rede. Na verdade, muitos pontos da rede eram, em 1991, áreas urbanas expressivas que reuniam toda a população urbana das localidades, como Manaus, Brasília e outros (ver anexo 1).

De outra parte, deve-se observar o peso relativo das localidades da rede tendo em vista suas classes de tamanho. Os dados da Tabela 2 mostram que, em 1991 as 10 maiores localidades respondiam por $61,4 \%$ da população da rede, em 2000 essa participação reduzse a $59.2 \%$.

Da mesma forma declinam as participações das grandes metrópoles de São Paulo e Rio de Janeiro. Paralelamente, ampliam-se os pesos dos subconjuntos com localidades de menor tamanho, especialmente os que reúnem as populações urbanas de municípios com mais de 200 mil e menos de um milhão de habitantes (de 23,7\% para 25,2\%). 
Tabela 1

População urbana dos municípios principais da rede de cidades Brasil - 1991 e 2000

\begin{tabular}{|c|c|c|c|}
\hline \multirow{2}{*}{$\begin{array}{l}\text { Localidades Principais da } \\
\text { Rede Urbana e } \\
\text { Subconjuntos }\end{array}$} & \multicolumn{3}{|c|}{ População Residente } \\
\hline & Cidades (1) & $\begin{array}{c}\text { Áreas } \\
\text { Urbanas } \\
(2)\end{array}$ & $\begin{array}{c}(1) /(2) \\
\%\end{array}$ \\
\hline RM de São Paulo & 14375974 & 15112917 & 95,12 \\
\hline RM do Rio de Janeiro & 7615853 & 9734529 & 78,24 \\
\hline RM de Belo Horizonte & 2712292 & 3257893 & 83,25 \\
\hline RM de Porto Alegre & 2800530 & 2914086 & 96,10 \\
\hline RM de Recife & 2252717 & 2732069 & 82,45 \\
\hline RM de Salvador & 2382875 & 2421340 & 98,41 \\
\hline RM de Fortaleza & 2064043 & 2249116 & 91,77 \\
\hline RM de Curitiba & 1750659 & 1877255 & 93,26 \\
\hline Brasília & 1515889 & 1515865 & 100,00 \\
\hline Manaus & 1006585 & 1006585 & 100,00 \\
\hline Subtotal & 38477417 & 42821655 & 89,86 \\
\hline 47 seguintes* & 14864851 & 16553924 & 89,80 \\
\hline 56 seguintes $* *$ & 7405302 & 8139755 & 90,98 \\
\hline 52 seguintes $* * *$ & 2172372 & 2229465 & 97,44 \\
\hline $\begin{array}{l}\text { Total Rede (165 } \\
\text { localidades) }\end{array}$ & 62919942 & 69744799 & 90,21 \\
\hline $\begin{array}{l}\text { Fonte: IBGE } \backslash \text { SIDRA (w } \\
* \text { localidades com popul } \\
\text { habitantes } \\
\text { ** localidades com popula } \\
\text { *** localidades com p } \\
\text { habitantes }\end{array}$ & $\begin{array}{l}\text { idra.ibge.gov.br } \\
\text { es urbanas entr } \\
\text { s urbanas entre } \\
\text { ações urbanas }\end{array}$ & $\begin{array}{l}200 \text { e um } \\
00 \text { e } 200 \mathrm{mi} \\
\text { inferiores }\end{array}$ & $\begin{array}{l}\text { ilhão de } \\
\text { bitantes } \\
100 \text { mil }\end{array}$ \\
\hline
\end{tabular}

Os dados indicam que nesses nove anos aumentou o estoque de população urbana da rede. O crescimento geométrico de 1,94\% a.a. no período ainda foi expressivo, embora inferior à média nacional de 2,45\%. Esse simples fato ao lado da redução do peso das grandes áreas urbanas são evidências do aprofundamento do processo de urbanização no país, nos moldes de uma urbanização desconcentrada apoiada na existência de um sistema de cidades suficientemente desenvolvido.

Os resultados apresentados na Figura 4 exibem o formato da rede urbana segundo as localidades centrais mais importantes do país, juntamente com suas articulações viárias representadas por segmentos de reta. Uma primeira forma de testar a consistência desses resultados é feita por meio de comparações com outros estudos que, de alguma maneira, contenham informações de fluxos capazes de exprimir a intensidade das relações entre as localidades. 
Tabela 2

População urbana dos municípios principais da rede de cidades e ritmo de crescimento demográfico entre 1991 e 2000

\begin{tabular}{l|r|r|r|r}
\hline Localidades Principais da & \multicolumn{4}{|c}{ População residente nas áreas urbanas } \\
\cline { 2 - 5 } Rede Urbana e & 1991 & $\%$ & 2000 & $\%$ \\
Subconjuntos & & & & \\
\hline RM de São Paulo & 15.112 .917 & 21,7 & 17.108 .619 & 20,6 \\
RM do Rio de Janeiro & 9.734 .529 & 14,0 & 10.074 .034 & 12,1 \\
RM de Belo Horizonte & 3.257 .893 & 4,7 & 4.114 .487 & 5,0 \\
RM de Porto Alegre & 2.914 .086 & 4,2 & 3.357 .728 & 4,0 \\
RM de Recife & 2.732 .069 & 3,9 & 3.047 .404 & 3,7 \\
RM de Salvador & 2.421 .340 & 3,5 & 2.973 .880 & 3,6 \\
RM de Fortaleza & 2.249 .116 & 3,2 & 2.760 .749 & 3,3 \\
RM de Curitiba & 1.877 .255 & 2,7 & 2.307 .439 & 2,8 \\
Brasília & 1.515 .865 & 2,2 & 1.961 .499 & 2,4 \\
Manaus & 1.006 .585 & 1,4 & 1.396 .768 & 1,7 \\
Subtotal & 42.821 .655 & 61,4 & 49.102 .607 & 59,2 \\
\hline 47 seguintes* & 16.553 .924 & 23,7 & 20.931 .871 & 25,2 \\
56 seguintes** & 8.139 .755 & 11,7 & 9.965 .772 & 12,0 \\
52 seguintes*** & 2.229 .465 & 3,2 & 2.915 .882 & 3,5 \\
\hline Total Rede (165 & 69.744 .799 & 100,0 & 82.916 .132 & 100,0 \\
localidades) & \multicolumn{4}{l}{} \\
\hline Fonte: IBGE $\backslash$ SIDRA (www.sidra.ibge.gov.br) \\
* localidades com populações urbanas entre 200 e um milhão de \\
habitantes \\
** localidades com populações urbanas entre 100 e 200 mil habitantes \\
*** localidades com populações urbanas inferiores a 100 mil habitantes
\end{tabular}

\section{7- COMPARAÇÕES COM DADOS DE FLUXOS MIGRATÓRIOS E DE SERVIÇOS}

Os fluxos migratórios são, sem dúvida, muito importantes em redes de países em desenvolvimento. Isto porque representam processos espaciais que aglutinam força de trabalho, pequenos capitais, informações e trocas de experiência, além de outras dimensões subjetivas alusivas à cultura, expectativas de sucesso, etc. As cidades que mais atraem migrantes são geralmente as que detém maior número de postos de trabalho, maiores oportunidades de consumo e prestação de serviços e maior grau de integração com outras áreas. Os fluxos migratórios podem, portanto, indicar características e sugerir o formato das áreas mais dinâmicas, as que gozam de funções dominantes e mais diversificadas na rede de localidades centrais do País. 
Figura 4

Rede Urbana Brasieira em Três Frações - 1991

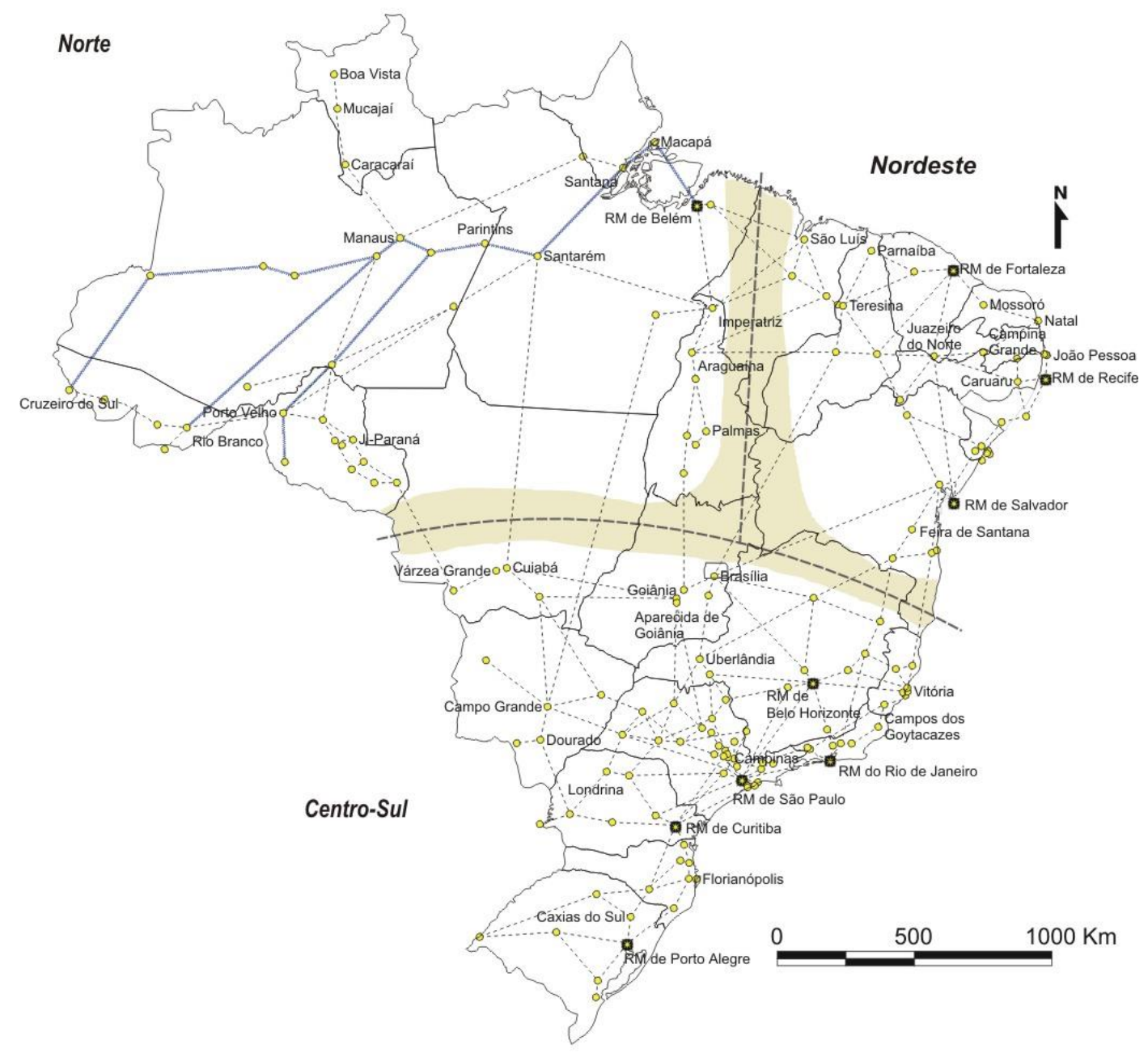

- Região Metropolitana

- Cidades

Articulações Viárias Predominantes

Rodoviária

\/ Fluvial
Mancha de Transição entre as Frações

--.- Divisão das Frações

Criação: Laboratório de Estodos Territóriais LESTE/IGC/UFMG

Em Matos (2001) obteve-se, a partir de dados ${ }^{18}$ de fluxos migratórios do período 1981-1991 para cada uma das cinco Grandes Regiões, um conjunto de mapas que

\footnotetext{
${ }^{18}$ Os dados se referem às microrregiões geográficas, definição instituída por regionalização elaborada em 1991 pelo IBGE. Por essa definição pode-se apontar quais são os espaços mais dinâmicos do País, uma vez que cada microrregião é também uma área de influência de uma cidade polo.
}

Cadernos do Leste

Artigos Cientificos

Belo Horizonte, Edição Especial, 2000 a 2008 
expressam bem as tendências atuais de configuração da rede urbana. Aos propósitos de comparação com a rede, são suficientes os dados de fluxo contendo entre mil e cinco mil imigrantes e mais de cinco mil imigrantes. ${ }^{19}$

A Fig. 5 exibe dois mapas com os dados de fluxo e um terceiro que sintetiza as informações mais relevantes superpostas em uma mancha branca sob o fundo cinza. Comparando o resultado com o mapa da rede urbana da Figura 4 obtém-se uma aproximação do que deve ser a área de abrangência da rede urbana brasileira. As coincidências são bastante evidentes já que os pontos da rede são recobertos pelas manchas que traduzem os fluxos migratórios mais intensos. Algumas segmentações espaciais dignas de nota podem ser descritas como se segue.

- A primeira delas refere-se ao vetor de expansão da economia paulista em direção ao norte do Paraná. A densidade dos fluxos na região permite inferir que estejam se estreitando os laços de interdependência econômica e social nesse subespaço, algo que se estende até o sul do Mato Grosso do Sul, onde já devem estar ocorrendo os impulsos resultantes da expansão de áreas vizinhas.

- A segunda expressa as articulações norte-sul de longa distância, estruturadas pelo corredor formado pela rodovia Transbrasiliana (BR-153). Em seu entorno figuram prósperas cidades da rede urbana brasileira, como Londrina, São José do Rio Preto, Uberlândia e Anápolis. Em sua extensão na bacia amazônica surgem vários pólos subregionais ao longo da rodovia Belém-Brasília.

- Menos densa que as anteriores, uma terceira área de destaque se desenvolve a partir de Cuiabá, no Mato Grosso, indo até a capital do estado de Rondônia, Porto Velho. Nas proximidades da fronteira do Brasil com Argentina e Paraguai, verifica-se a emergência de importantes segmentos da rede de fluxos, interligados desde o norte do Paraná até o estado do Acre. Trata-se afinal de uma conhecida rota de migrantes internos, sobretudo nos anos de 1970.Outra área importante situa-se entre o Maranhão e o Pará. Abrange uma boa quantidade de microrregiões que devem estar configurando novas articulações capitaneadas por Belém, Brasília e Palmas- Araguaína. ${ }^{20}$

\footnotetext{
${ }^{19}$ Embora, para efeito de simplificação, só compareçam nos mapas aqui apresentados os fluxos intrarregionais, há evidentes níveis de interação entre as dinâmicas intra e inter-regionais.

${ }^{20}$ Ao longo da Transbrasiliana, movimentos migratórios expressivos destacam-se em áreas de ocupação mais antiga, sobretudo nas proximidades das metrópoles de Belém e Brasília. Rumo ao litoral, entre os estados do Maranhão e Pará, os fluxos foram significativos, reforçando portanto a idéia de que vêm surgindo novas articulações na rede de cidades, derivadas da afirmação de centros de porte intermediário, sobretudo na porção norte-nordeste do Brasil.

Cadernos do Leste

Artigos Cientificos

Belo Horizonte, Edição Especial, 2000 a 2008
} 


\section{Figura 5 \\ Fluxos Migratórios entre Microrregiões Geográficas das \\ Grandes Regiões Brasileiras - 1981/91}

Fluxos de 1.000 a 5.000 migrantes

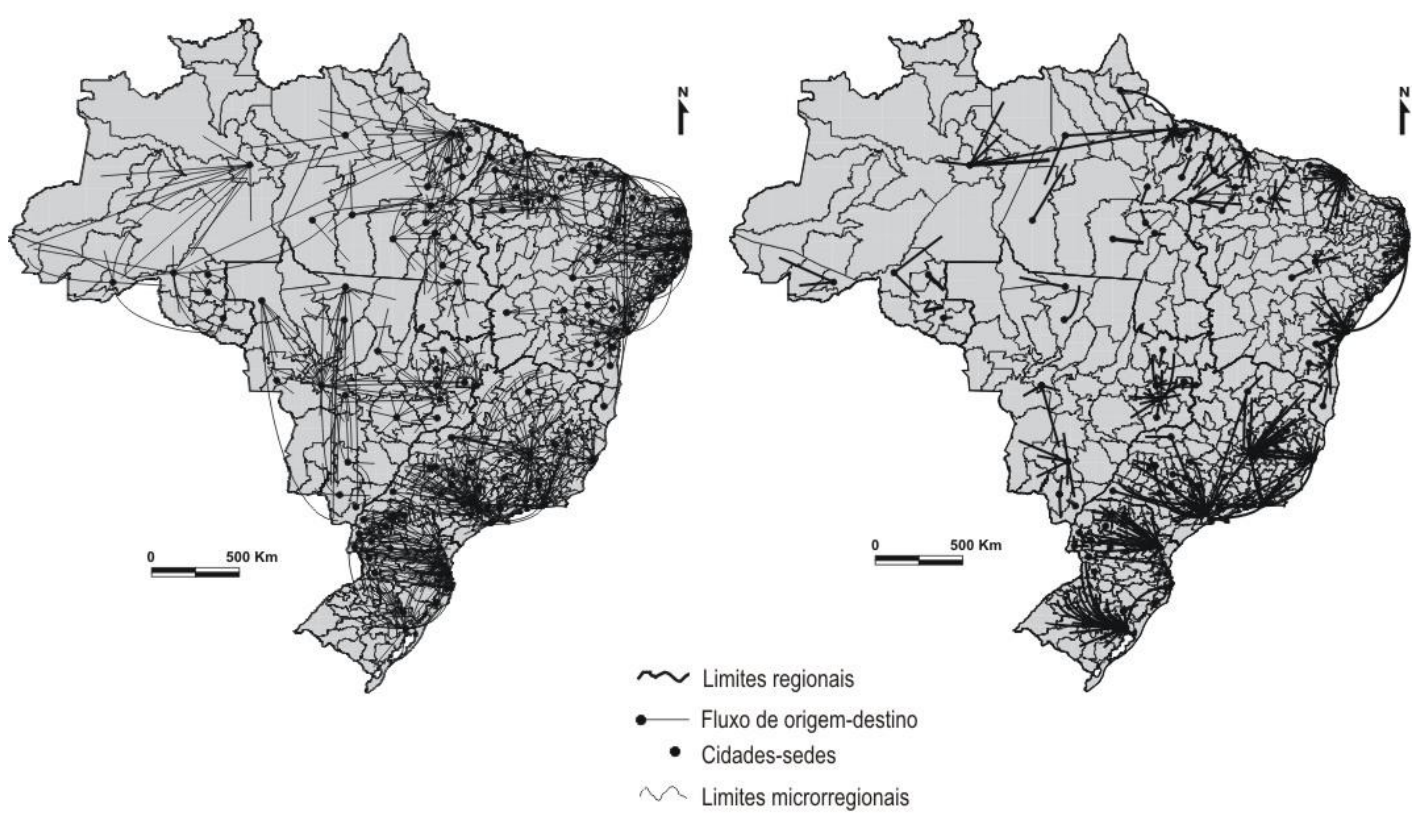

Fluxos superiores a 5.000 migrantes

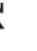

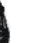


Outra comparação com o desenho geral da rede urbana pode ser feita com informações mapeadas em SANTOS e SILVEIRA (2001) sobre infraestrutura e serviços, especialmente quando discutem a 'formação da Região Concentrada e a urbanização interior' e introduzem a questão da integração nacional. Três dos mapas temáticos apresentados são ricos de significações e auxiliam a verificação da consistência da rede urbana aqui proposta (ver Fig. 6 e 7).

O primeiro deles retrata "os sistemas de engenharia”. Expõe a localização de rodovias, ferrovias, hidrovias, portos e aeroportos, expressões geográficas sem as quais não se formam as redes de localidades centrais. Um aspecto curioso e digno de nota refere-se a importância das hidrovias para a afirmação e sobrevivência de muitas cidades ribeirinhas das bacias dos rios Amazonas, Tocantins e São Francisco (aspecto esse sublinhado na proposta de rede aqui apresentada). Isto tanto reflete as rugosidades derivadas de um passado 'pré-mecânico', como quer Milton Santos, como potencialidades de ganhos econômicos em termos de circulação de mercadorias no mundo globalizado da atualidade. Nesse sentido, na bacia do Prata, a hidrovia do Tietê-Paraná merece destaque, especialmente em sua extensão no estado de São Paulo, onde se situa a mais densa rede geográfica do País.

O segundo mapa temático mostra a distribuição das agências bancárias no Brasil em 1997. Reflete a espacialidade da financeirização do capital, a circulação de bens e serviços, o potencial de crédito e investimentos e a presença de bancos oficiais, geralmente os primeiros a se instalarem em áreas pioneiras. ${ }^{22}$ Nesse caso fica muito evidente o grande peso do Sul-Sudeste, interconectado com o sudeste do Mato Grosso do Sul e com o entorno do Distrito Federal e Goiânia. Secundariamente comparece toda a franja litorânea nordestina onde é também expressivo o número de agências bancárias.

A Figura 7 mostra também o mapa que exibe a distribuição de um serviço só disponível nos últimos anos, o da telefonia celular. Os dados relativos a 1997 permitem indicar de forma bastante clara não só a tendência de distribuição atual das áreas urbanas mais dinâmicas do País, mas também apontam para os subespaços ainda não cobertos por esse novo serviço (como as porções setentrionais do Norte, Centro-Oeste e interior de vários estados a exemplo de Minas Gerais e Bahia). Ficam evidenciadas: i) a

Janeiro mostram-se especiais, pois além de receberem migrantes de todo o Sudeste, eram as metrópoles mais procuradas pelos migrantes nordestinos. A região metropolitana de São Paulo, por seu turno, possui uma dinâmica econômico-espacial mais complexa, já que além de redistribuir também perde população para o interior do estado e resto do País.

${ }^{22}$ Em outro mapa do mesmo trabalho fica evidente a presença do Banco do Brasil em importantes subespaços da rede de cidades, como no litoral e interior do Nordeste e no Centro-Oeste, inclusive ao longo do eixo da Belém-Brasília, e no eixo Boa Vista-Porto Velho-Cuiabá. 


\section{Figura 6}

\section{Distribuição dos Sistemas de Engenharia}

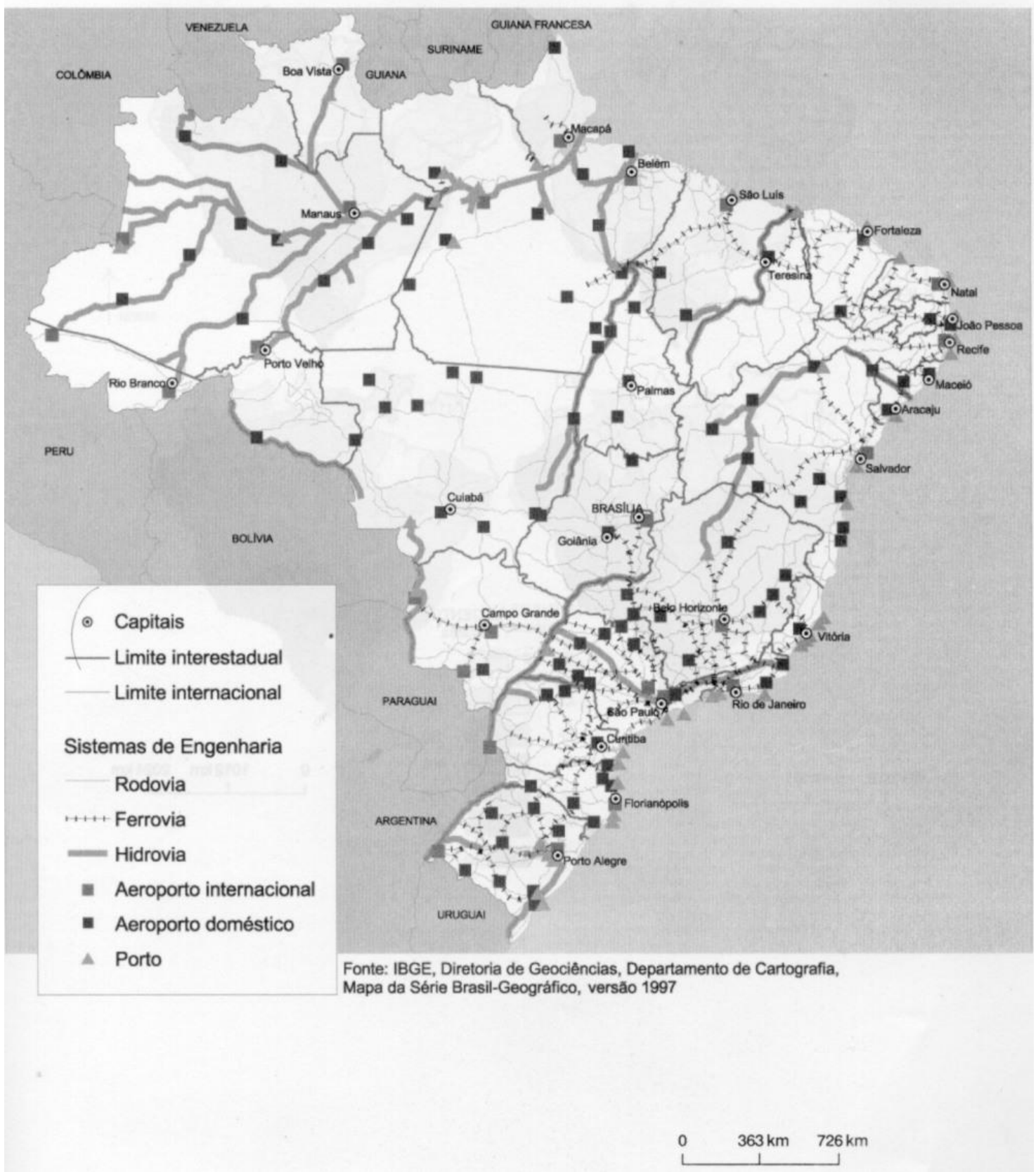

Cadernos do Leste 


\section{Figura 7}

\section{Distribuição Geográfica do Sistema de Telofonia Celular e das}

Agências Bancárias no Brasil em 1997
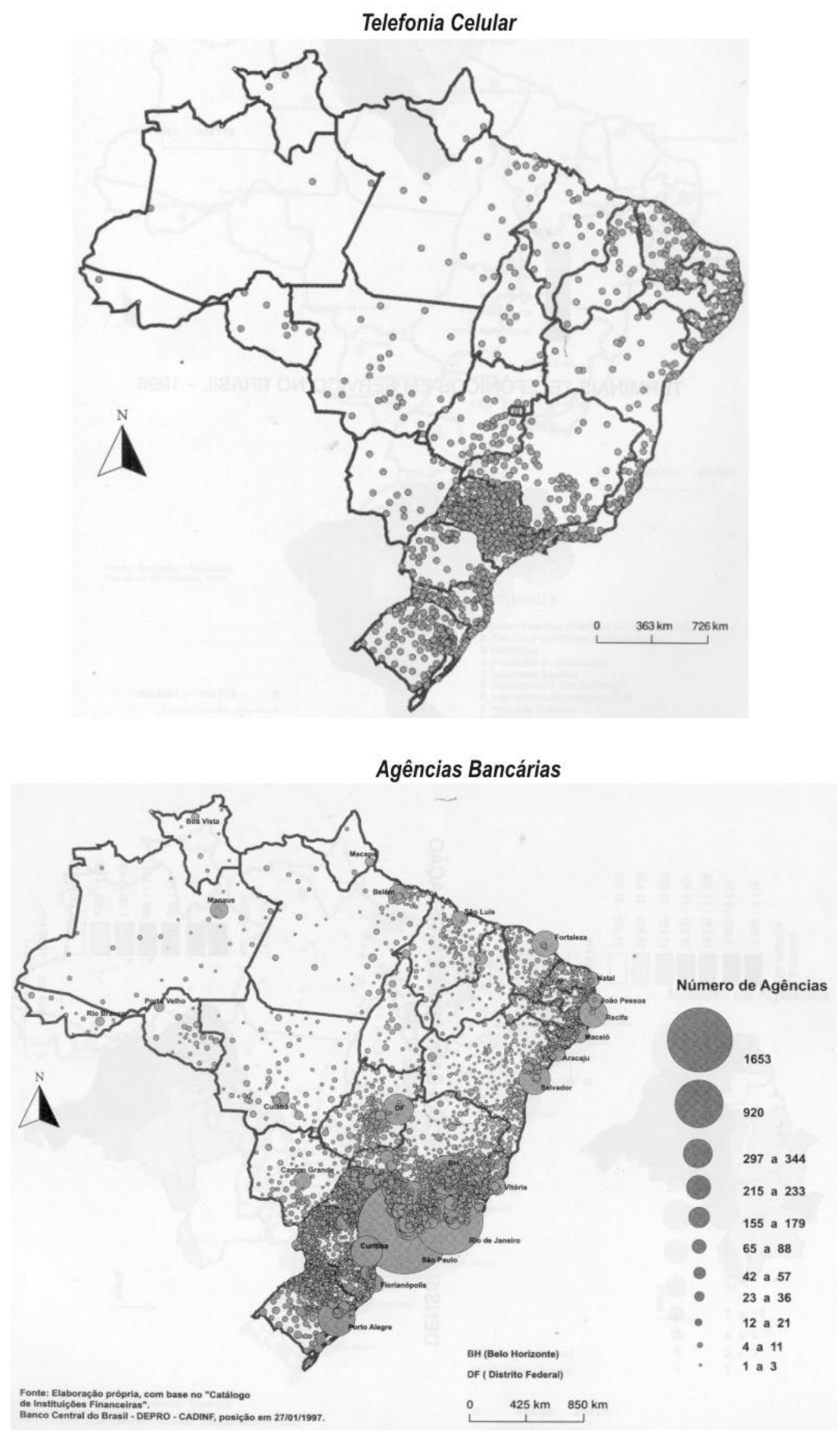

importância dos estados do Sul e Sudeste (com o forte destaque de São Paulo); ii) a aglutinação de subespaços do Mato Grosso do Sul, Minas Gerais e Goiás (sobretudo nas proximidades do estado de São Paulo); iii) a afirmação das áreas litorâneas e de parte do interior do Nordeste.

Cadernos do Leste 
A superposição das informações dos três mapas temáticos, conforme as manchas de recobertura, comparada com o espaço formado pela rede de cidades aqui apresentada, mostra coincidências indiscutíveis e permite concluir que: a) os "sistemas de engenharia" guardam forte proximidade com a localização das áreas mais diretamente sobre influência das cidades integrantes da rede urbana aqui proposta; b) as manchas que recobrem a distribuição geográfica das agências bancárias ultrapassam a área de influência da rede urbana. Isto deve se explicar em razão da presença muito difusa dos bancos por quase todas as cidades brasileiras, muitas delas de pouca expressão no processo de urbanização; c) as manchas correspondentes ao serviço de telefonia aproximam-se, em muitos trechos, da localização dos pontos da rede urbana, complementando-a, especialmente se for comparada com os sistemas de engenharia. Trata-se de uma peculiar coincidência, em face das características específicas desse serviço; flexível, de alcance espacial supra-local, avançado tecnologicamente e envolvendo investidores internacionais.

\section{8- A REDE EM TRÊS FRAÇÕES}

A configuração espacial da rede urbana principal mostrada na Figura 4 permite visualizar subconjuntos relativamente notáveis no interior do mapa do Brasil, certamente dotados de níveis de estabilidade significativos. Essa observação deve ser balisada por algum tipo de critério espacial elementar, como por exemplo a intensidade relativa das articulações entre os pontos no interior de cada subconjunto, ou o grau de densificação e posição dos componentes desses subconjuntos. Uma forma de resolver esta questão é verificar o padrão mínimo de distâncias entre os nódulos, de sorte que fique explicitado que o gradativo aumento dessas distâncias implica concomitante diminuição da densificação. A posição e localização desses subconjuntos podem ser um critério, que objetiva a eliminação de situações marginais ou excepcionais. Por exemplo, trechos da rede urbana localizados em áreas de fronteira podem incorporar-se ao polo dominante mais próximo, mesmo que tal trecho esteja pouco articulado com o resto do país por manter fortes articulações com algum país vizinho.

O desenho da rede mostra que nas áreas meridionais do país há um grande número de nódulos separados por distâncias relativamente pequenas entre si. Aqui a densificação da rede é muito expressiva sobretudo nas proximidades das metrópoles de São Paulo e Rio de Janeiro. As distâncias entre as cidades, de acordo com os segmentos pontilhados que traduzem a existência de ligações viárias, raramente ultrapassam os $250 \mathrm{~km}$. Contudo, à medida que a rede avança para o Centro Oeste e o Nordeste essas distâncias aumentam. 
A fração Centro-Sul passa a ser constituída pelo Sul e amplas porções do Sudeste e Centro Oeste, que abrigam em seus espaços mais centrais um grande número de localidades urbanas geradoras de uma configuração de rede intrincada e densa, com múltiplas articulações viárias. Esse desenho só perde intensidade a partir de Brasília e Distrito Federal, em direção a Palmas e Araguaína; a partir das conexões de Minas Gerais com o sul/sudoeste da Bahia; e nas proximidades da fronteira do país com Uruguai, Argentina, Paraguai e Bolívia.

Uma outra fração da rede, bem menor que as demais, mas claramente discernível, localiza-se no nordeste brasileiro e não ultrapassa os limites da Grande Região homônima. A história do povoamento costeiro apoiada na atividade açucareira e as fragmentações territoriais ao longo dos séculos (entre, por exemplo, Bahia, Pernambuco e Ceará) deram a esse subconjunto uma feição visualmente nítida, especialmente no arco que envolve Fortaleza, Natal, Recife, Maceió, Aracaju, Salvador, Petrolina/Juazeiro e Juazeiro do Norte. Todavia, a rede aqui, em seus 37 centros articulados por rodovias a partir de Vitória da Conquista até São Luis do Maranhão, é bem menos densa que a do Centro Sul, com centros separados por distâncias médias superiores aos $250 \mathrm{Km}$.

Após definidas essas duas grandes divisões poder-se-ia, por exclusão, nomear o que sobrou como resto do Brasil. Entretanto, essa vasta porção adicional coincide em grande medida com a chamada Amazônia Legal brasileira, reunindo integralmente a Grande Região Norte e parte do Centro Oeste. Seguindo Geiger ou orientações de estudiosos que destacavam os critérios baseados na "região natural", pode-se recorrer a ideia de Hiléia e nomeá-la como fração amazônica. Contudo, para manter certa coerência com as denominações geográficas anteriores, Centro Sul e Nordeste, adota-se a denominação fração norte da rede urbana. É evidente que nesse caso as distâncias viárias são muito maiores (em muitos casos superiores aos $500 \mathrm{Km}$ ) e a condição mais rarefeita e fragmentada da rede se impõe, o que faz surgir pelo menos três subconjuntos: um ao longo de Belém-Brasília, outro na porção ocidental de Mato Grosso e Acre, e o último no corredor fluvial do rio Amazonas. De fato, apenas nessa fração os condicionantes do quadro natural se fazem tão marcantes a ponto de influir na configuração e formato da rede.

Os mapas da Figura 8 expõem o desenho da rede urbana principal em três frações e sintetizam parte da dinâmica territorial em curso no Brasil das últimas duas décadas. Os 
dados de crescimento demográfico permitem agregar novos comentários sobre cada uma das frações ${ }^{23}$.

Figura 8

Crescimento Geométrico da População nas Localidades da Rede População Urbana

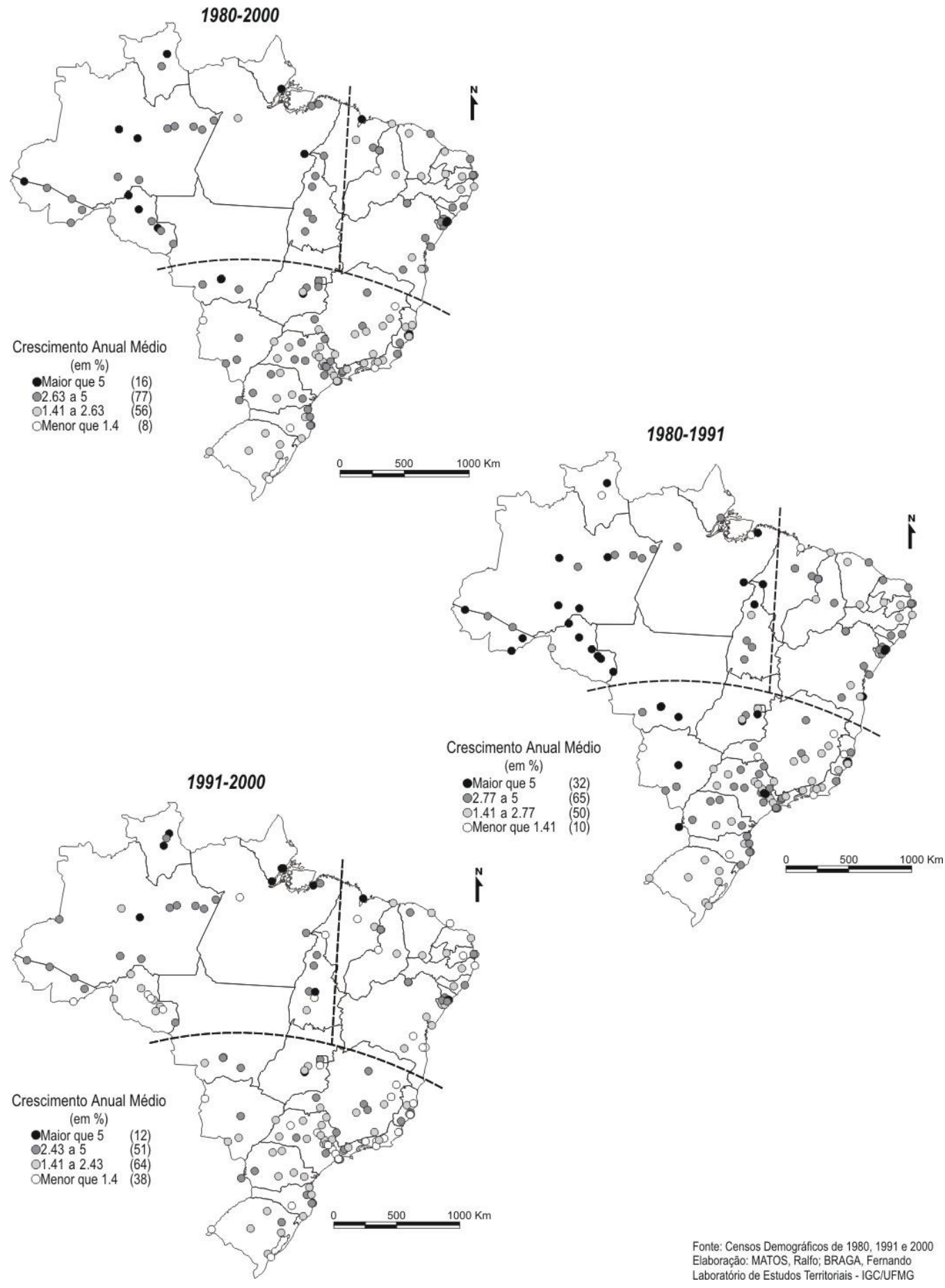

${ }^{23}$ Em 1991, havia 17 nódulos cuja população urbana ultrapassava os 500.000 habitantes. Afora as nove Regiões Metropolitanas, cabe mencionar Goiânia, Campinas e Campo Grande (no Centro Sul); Natal, Maceió e Teresina (no Nordeste) e apenas Manaus e Belém do Pará na porção Norte. Em 1996, o número de centros com mais de 500 mil habitantes chega a 19, com a entrada de São Luis e João Pessoa, ambos da região Nordeste. Já no ano 2000 esse conjunto amplia-se até 21 pontos, com a inclusão de mais duas cidades do estado de São Paulo, São José dos Campos e Ribeirão Preto.

Cadernos do Leste

Artigos Cientificos

Belo Horizonte, Edição Especial, 2000 a 2008 


\section{9- CARACTERÍSTICAS POPULACIONAIS DAS FRAÇÕES DA REDE DE CIDADES}

FRAÇÃO NORTE - Nessa parte da rede urbana brasileira, as principais áreas de atração continuam sendo Belém e Manaus, as únicas com estoques populacionais superiores a um milhão de habitantes em 2000, ambas convivendo com um acelerado processo de urbanização.

Dignas de nota são as 16 cidades com populações variando entre 50 e 250 mil habitantes, embora centros com menos de 50 mil habitantes (18) ostentem importância na estrutura espacial da Região.

Pela função articuladora que exercem na rede dentrítica regional e pelos estoques de população urbana que ostentavam em 2000, cabe citar as cidades de Castanhal, Araguaína, Imperatriz, Marabá e Palmas, no vetor norte-sul da chamada 'Transbrasiliana', além de Santarém, Boa Vista e Rio Branco, estas duas últimas capitais estaduais. Tais centros estão na classe de cidades com populações variando entre 100 e 250 mil habitantes, e expressam bem a importância funcional dos centros de tamanho intermediário na Amazônia.

$\mathrm{Na}$ fração Norte, a grande maioria dos núcleos urbanos exibia taxas de crescimento demográficos superiores à média nacional, à exceção dos municípios da franja oeste, nas proximidades de Ji-Paraná, onde o esgotamento da fronteira e fracassos nos projetos de colonização fizeram surgir refluxos migratórios expressivos. Aliás, o êxodo rural nos próprios municípios parece ocorrer em grande parte da Região e deve explicar o diferencial entre o crescimento das populações urbana e total.

Destarte, os dados de crescimento populacional no período indicam que as tendências de consolidação de determinados eixos de expansão na rede urbana regional parecem ser consistentes. Notadamente nos eixos que articulam, de um lado, Macapá-Belém com Brasília e, de outro lado, o ramo ocidental da rede que articula longitudinalmente cidades do Acre, Rondônia e Mato Grosso. Ritmos de crescimento superiores a 5\% a.a., bem acima da média nacional, são encontrados em várias das cidades da rede, a exemplo de Palmas, Belém, Caracaraí, Macapá, Santana, Laranjal do Jari, Feijó e Sena Madureira.

Por outro lado, verifica-se a existência de um bom número de cidades que concentram população inferior a 50.000 habitantes, número que decresce no período analisado, de 29 municípios em 1991 a 18 em 2000. Em 1991 havia 42 nódulos na rede e em 2000 esse número reduziu-se a 38. Com isto, tanto desaparecem alguns nódulos 'incipientes', quanto aumenta o adensamento nos principais pólos regionais, especialmente os localizados ao longo da rede fluvial.

Cadernos do Leste

Artigos Cientificos

Belo Horizonte, Edição Especial, 2000 a 2008 
FRAÇÃO NORDESTE - Nesse subespaço predomina um ritmo de crescimento demográfico inferior à média nacional, embora em 16 municípios a população total tenha aumentado entre 1991 e 2000 a taxas superiores à média brasileira. O fato de o Nordeste ser uma região historicamente expulsora de população explica parte dessas evidências. Além disso, os dados indicam que as saídas de população de áreas rurais para áreas urbanas ainda é uma característica marcante em muitos municípios que possuem cidades em expansão, sobretudo nos localizados no litoral e proximidades.

No ano 2000 havia na Região oito núcleos urbanos com maior tamanho populacional (mais de 500 mil habitantes) e 23 com populações variando entre 100 e 500 mil habitantes. O predomínio das cidades médias no conjunto de centros da rede regional é bastante evidente. Afinal, abaixo desta classe de tamanho constavam apenas seis centros, cinco com população variando entre 50 e 100 mil habitantes e apenas um com menos de 50 mil habitantes, conforme mostram os dados da Figura 6.

$\mathrm{Na}$ fração Nordeste ainda existem áreas que exibem parte das heranças históricas da ocupação litorânea, em subespaços relativamente densos onde se localizam as capitais e regiões metropolitanas, e em trechos interconectados por cidades do Agreste e do Sertão. Estados como Bahia, Pernambuco, Ceará e Rio Grande do Norte têm participado com núcleos urbanos mais dinâmicos e de maior tamanho populacional, a exemplo de Salvador, Recife, Fortaleza, São Luiz, Natal, Garanhuns e Barreiras. Por outro lado, observa-se alguma redução do grau de centralidade urbana em determinadas áreas dos estados do Piauí e partes do Maranhão.

A FRAÇÃO CENTRO SUL - Em situação bem distinta, a fração Centro-Sul continua aumentando sua presença na rede urbana nacional, interagindo com núcleos urbanos históricos do litoral sul-sudeste, mas sobretudo articulando-se a extensas áreas do interior do Sudeste, Sul e Centro Oeste.

Ao reunir o maior estoque de residentes urbanos do País, ostenta sete grandes áreas urbanas com mais de um milhão de habitantes, quatro com populações entre 500.000 e 1.000.000 de habitantes e 91 cidades de porte médio (com populações entre 100 e 500 mil). Se mantidos os critérios da rede urbana aqui proposta, várias cidades se integrariam à fração Centro Sul entre 1991 e 2000 com mais de 100 mil habitantes.24

Os dados da Figura 9, aparentemente, indicam um paradoxo: nesse subespaço 66,1\% dos nódulos apresentaram um crescimento da população total superior à média nacional no

\footnotetext{
${ }^{24}$ A exemplo de Patos de Minas, Barbacena e Varginha em Minas Gerais; Angra dos Reis no Rio de Janeiro; Itapetinga, Bragança Paulista, Jaú, Botucatu, Cubatão e Catanduva, todos em São Paulo; Apucarana no estado do Paraná; e, Rio Verde e Águas Lindas de Goiás na Federação de Goiás.

Cadernos do Leste

Artigos Cientificos

Belo Horizonte, Edição Especial, 2000 a 2008
} 
período 1991-2000, enquanto apenas 30,3\% do crescimento das populações urbanas dos mesmos 109 nódulos situaram-se acima da média nacional. Isto se explica basicamente pelas seguintes razões: i) muitos dos centros urbanos do Centro Sul detém altos estoques de populações urbanas já há décadas, o que não favorece a continuidade do crescimento demográfico a taxas muito altas; ii) muitos municípios estão saturados em termos de oferta de áreas urbanizáveis, apresentando valores de acesso aos imóveis urbanos extremamente elevados; iii) a 'rurbanização', isto é a ocupação de áreas rurais com atividades urbanas tem sido uma estratégia de redução de custos imobiliários posta em prática nos últimos anos por famílias e firmas; iv) o processo de desconcentração populacional atinge áreas rurais de vários municípios prósperos da densa rede urbana do Sudeste, assim como alcança a periferia dessa rede, onde a expansão demográfica é superior a dos núcleos mais centrais. 


\section{Figura 9}

\section{Comparações entre o Crescimento Médio das populações Total e Urbana das Localidades da Rede Urbana com as Médias Nacionais - 1991/2000}

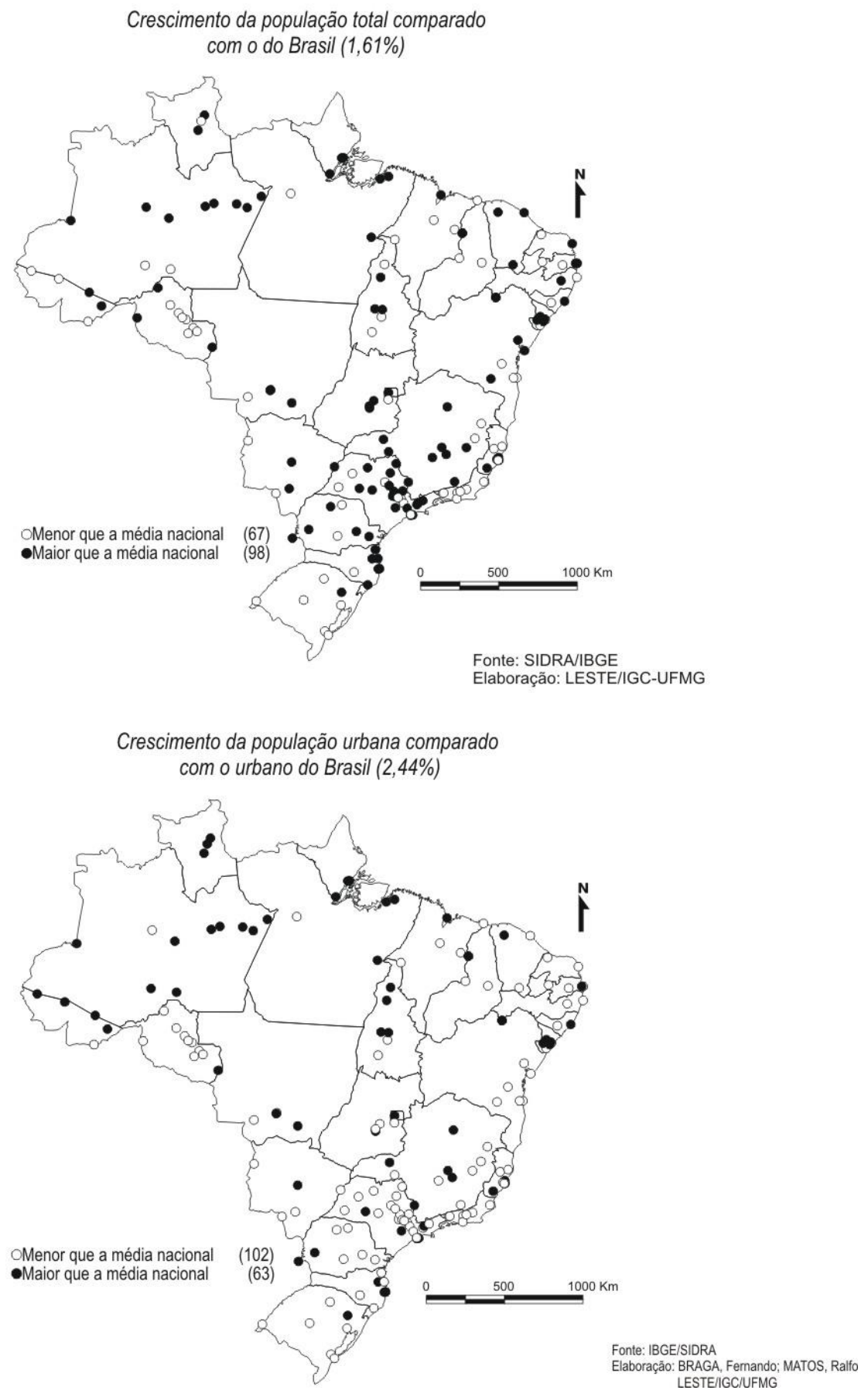

Os mapas mostram não só a configuração mais intrincada da rede nas proximidades da Região Metropolitana de São Paulo (RMSP), mas também indicam quais são os centros de maior crescimento: os localizados nas proximidades da própria RMSP, os localizados na Transbrasiliana e os do Oeste do Paraná. 
Por outro lado, já se pode verificar também a existência de vários centros de crescimento populacional negativo ou muito baixo, como os da própria RMSP.

Na verdade, nas proximidades da Grande São Paulo estão reunidas algumas das principais áreas urbanas do País, várias delas relativamente saturadas e com dificuldades de suprir um grande número de residentes com serviços urbanos de qualidade.

De modo geral, percebe-se uma intensificação da rede de cidades, prefigurando o que alguns autores denominam de 'desconcentração concentrada', já que os novos pontosnódulos estão muito próximos de grandes centros urbanos e nas imediações de importantes entroncamentos rodoviários.

\section{0- OS TRÊS BRASIS DESIGUAIS}

As vantagens em se produzir uma divisão espacial aglutinando grandes extensões territoriais são evidentes pela própria simplificação em si. A geografia econômica frequentemente requer esse tipo de generalização. As características básicas de cada espaço e a perspectiva de se lograr obter visões sintéticas e abrangentes da realidade social estão sempre presentes quando se estuda um país da dimensão física do Brasil. Pode-se, portanto, defender a ideia de que há três brasis, e não dois ou quatro, e tentar explicitar melhor esses espaços. Seguindo a tradição das análises referidas na primeira parte desse estudo, quando procuravam expressar desigualdades dicotômicas de caráter social e econômico, pode-se examinar os dados censitários segundo setores de atividade dos ocupados, renda familiar e sexo.

As Tabelas apresentadas a seguir retratam o Brasil de 1991, no qual pouco menos de 29 milhões de pessoas constituía a população economicamente ativa recenseada nos 165 pontos da Rede Urbana aqui apresentada. Desse total, a grande maioria residia no Centro Sul, cerca de 76\% (21.456.622 pessoas), enquanto a fração Nordeste acumulava quase 18\% (5.044.706 pessoas) e a fração Norte apenas 6\% (1.728.367 pessoas).

\section{Ocupados por setores de atividades ${ }^{25}$}

Pelos dados censitários de 1991 é possível encontrar indicações de especialização em termos de atividades econômicas que mais ocupavam mão-de-obra, a ponto de evidenciar diferenças significativas entre as frações da rede urbana aqui analisada? Os dados

\footnotetext{
${ }^{25}$ Os setores de atividade são agrupamentos dos ramos de atividade, constituídos em função da finalidade ou ramo de negócio da organização, empresa ou entidade a que prestassem serviços, ou de acordo com a natureza da atividade exercida, para os que trabalhavam por conta própria.
}

Cadernos do Leste

Artigos Cientificos

Belo Horizonte, Edição Especial, 2000 a 2008 
mostram algumas tendências significativas mas sem a precisão desejável, devido às dificuldades existentes em critérios e definições utilizadas pelo IBGE nos levantamentos censitários, sobretudo no que tange à inserção do ocupado em atividades formais e informais do mercado de trabalho.

Uma dificuldade nas análises por setores de atividade diz respeito a alguns ramos típicos do chamado terciário urbano, que ocorrem por toda a rede de cidades. Por exemplo, em todas as três frações a Prestação de Serviços ${ }^{26}$ é o setor de atividade que mais ocupa a população economicamente ativa (Tabela 3). A questão, que não é objeto de análise nesse estudo, é dizer quais eram os serviços que caracterizavam cada um desses subespaços. Indicações de que no Nordeste e Norte o perfil profissional dos ocupados nessa atividade fosse mais modesto do que no Centro Sul, em termos de requerimentos profissionais, podem ser deduzidas pela maior concentração de pessoas remuneradas com até um salário mínimo, $62,6 \%$ e $67,5 \%$, respectivamente, contra 45,4\% no Centro Sul. No extremo oposto, nos setores Social e Administração Pública, os com mais de cinco salários mínimos só eram proporcionalmente mais expressivos no Centro Sul, 22,7\% e 19,1\% (cf. Tabela 4).

Ao que tudo indica, algumas atividades da Tabela 3 podem ser reunidas de modo a sinalizar para padrões, mais ou menos modernos, característicos das economias regionais que estruturam as três frações da rede urbana aqui analisada.

No âmbito dos serviços pode-se considerar que o setor Transportes e Comunicação, os Serviços Auxiliares da Atividade Econômica ${ }^{27}$, e o setor Outras Atividades $^{28}$ reúnem mais profissionais especializados dos que são requisitados por atividades "não-tradicionais" do que, por exemplo, o comércio de mercadorias. Esse conjunto de atividades, mais presente no Centro Sul, ocupava cerca de 15\% da PEA em 1991, enquanto no Norte e Nordeste ocupavam entre 10 e 11\% do total (Tabela 3).

\footnotetext{
26 A "Prestação de Serviços" abrange as atividades relacionadas a alojamentos e alimentação, reparação e conservação, serviços pessoais, domiciliares e diversões.

27 Os "Serviços Auxiliares da Atividade Econômica" compreendem as atividades de técnicos profissionais e auxiliares das atividades econômicas.

28 "Outras Atividades" agrega os indivíduos relacionados a instituições de crédito, seguros e capitalização, comércio e administração de imóveis e valores mobiliários, organizações internacionais e representações estrangeiras e as atividades não compreendidas nos demais ramos de atividade, mal definidas ou não declaradas.

Cadernos do Leste

Artigos Cientificos

Belo Horizonte, Edição Especial, 2000 a 2008
} 
Tabela 3

Distribuição proporcional da população economicamente ativa nos setores de atividade das frações da rede urbana - 1991

\begin{tabular}{l|r|r|r}
\hline Setor de atividade & Norte & Nordeste & $\begin{array}{c}\text { Centro- } \\
\text { Sul }\end{array}$ \\
\hline Atividades agropecuárias, de extração vegetal e pesca & 14,95 & 6,64 & 2,74 \\
Indústria de transformação & 11,14 & 12,06 & 21,08 \\
Indústria da construção civil & 7,30 & 7,91 & 7,72 \\
Outras atividades industriais & 3,41 & 2,17 & 1,68 \\
Comércio de mercadorias & 16,28 & 17,54 & 15,09 \\
Transporte e comunicação & 5,12 & 4,86 & 5,64 \\
Serviços auxiliares da atividade econômica & 2,76 & 3,19 & 4,89 \\
Prestação de serviços & 18,56 & 23,37 & 21,42 \\
Social & 10,36 & 12,24 & 10,29 \\
Administração Pública & 7,77 & 6,99 & 5,13 \\
Outras atividades & 2,35 & 3,03 & 4,34 \\
Total & $100 \%$ & $100 \%$ & $100 \%$ \\
\hline Fon & & &
\end{tabular}

Fonte: Censo Demográfico de 1991 (dados amostrais)

Um outro conjunto de atividades do terciário urbano que reúne muitos profissionais qualificados é o denominado setor "Social". Nele estão as atividades comunitárias, os serviços médicos e odontológicos e os de ensino. A presença generalizada de muitos desses trabalhadores nas grandes cidades, sobretudo nas atividades de ensino, dificulta a comparabilidade. Contudo, os níveis de remuneração e a diversificação desse setor são muito maiores e melhor distribuídos no Centro Sul relativamente ao Norte e Nordeste.

Os ocupados na Administração Pública distribuem-se entre os vários órgãos públicos das três esferas de governo, muitos dos quais na segurança pública e defesa nacional. Nesse caso, comparece com mais ênfase as frações Norte e Nordeste, com seus $7,8 \%$ e $7,0 \%$ de ocupados, contra os $5,1 \%$ da fração Centro Sul. A maioria desses profissionais detinha baixa remuneração (um pouco menos no Centro Sul), embora, em todas as frações, a distribuição segundo classes de renda não revelasse fortes desigualdades. Pelo visto, os postos de trabalho associados às administrações públicas mostravam-se importantes em todo o país em 1991, e constituíam um meio de reduzir disparidades de renda intra e inter-regionais.

Dignos de nota por absorver muita mão-de-obra não qualificada ou semiqualificada são os setores de comércio de mercadorias e da construção civil. Contudo tais setores não servem para diferenciar os subespaços aqui analisados porque são de tipo ubíquo, presentes em todas as cidades, embora ligeiramente predominantes nas frações Norte e Nordeste. 
Os setores de atividade que estabelecem diferenças mais notáveis entre as frações são basicamente dois, o da Indústria de Transformação e o das atividades Agropecuárias, de Extração Vegetal e Pesca. O primeiro mostra-se muito mais expressivo no Centro Sul, já que congregava 21,1\% dos 21.443 .092 ocupados em 1991. O Nordeste e o Norte também ocupavam proporções expressivas de trabalhadores em atividades industriais, embora no caso do Norte, sem a presença da Zona Franca de Manaus, certamente a proporção de 11,1\% de ocupados reduzir-se-ia bastante. O segundo setor mostra uma clara idiossincrasia. Somente na fração Norte esse setor chega a ocupar 15\% da PEA, fazendo visível contraste com o Centro Sul e Nordeste. As chamadas outras atividades industriais, por reunir a extração mineral e os serviços industriais de utilidade pública também são mais expressivas no Norte em relação ao Nordeste e Centro Sul.

Alguns comentários gerais com base na Tabela 4 indicam que: i) a maioria da PEA ocupada e remunerada auferia até um salário mínimo (perto de 57\% na fração Norte e 63\% no Nordeste). Em alguns setores, os níveis de remuneração eram mais baixos, a exemplo das Atividades Agropecuárias, Extração Vegetal e Pesca; Construção Civil e Indústria de Transformação, especialmente se localizados nas frações Norte e Nordeste; ii) outros setores entretanto - como já observado - ocupavam trabalhadores com níveis de remuneração mais elevados, a exemplo dos Serviços Sociais, Administração Pública, Outras Atividades Industriais, Outras Atividades, e Auxiliares da Atividade Econômica; iii) na comparação entre as frações, o Centro Sul, sem dúvida mostrava-se menos desigual, pois tanto detinha, proporcionalmente, mais ocupados recebendo acima de cinco salários mínimos, quanto muito mais trabalhadores na situação intermediária (com remuneração entre um e cinco salários mínimos). 
Tabela 4

Distribuição percentual da PEA ocupada segundo classes de rendimento médio mensal per capita em salários mínimos (s.m.) de 1991 por frações da rede urbana

\begin{tabular}{|c|c|c|c|c|c|c|c|c|c|}
\hline \multirow[t]{2}{*}{ Setor de atividade } & \multicolumn{3}{|c|}{ Fração Norte } & \multicolumn{3}{|c|}{ Fração Nordeste } & \multicolumn{3}{|c|}{ Fração Centro Sul } \\
\hline & Até 1 & $\begin{array}{l}+1 \text { a } \\
5\end{array}$ & +5 & até 1 & $\begin{array}{l}+1 \mathrm{a} \\
5\end{array}$ & +5 & até 1 & $\begin{array}{ll}+1 & \mathrm{a} \\
5\end{array}$ & +5 \\
\hline $\begin{array}{l}\text { Ativ. agrop, ext. veg. e } \\
\text { pesca }\end{array}$ & 86,1 & 12,5 & 1,3 & 90,8 & 7,6 & 1,6 & 65,8 & 28,3 & 5,9 \\
\hline $\begin{array}{l}\text { Indústria de } \\
\text { transformação }\end{array}$ & 59,1 & 36,5 & 4,5 & 70,1 & 25,6 & 4,2 & 34,0 & 57,4 & 8,6 \\
\hline $\begin{array}{l}\text { Indústria da construção } \\
\text { civil }\end{array}$ & 70,2 & 27,6 & 2,3 & 81,4 & 16,2 & 2,3 & 53,1 & 42,6 & 4,3 \\
\hline $\begin{array}{l}\text { Outras atividades } \\
\text { industriais }\end{array}$ & 42,2 & 38,2 & 19,6 & 57,4 & 34,6 & 8,0 & 35,8 & 50,8 & 13,4 \\
\hline Comércio de mercadorias & 52,5 & 40,3 & 7,2 & 62,6 & 31,9 & 5,5 & 33,3 & 55,6 & 11,1 \\
\hline Transporte e comunicação & 52,4 & 42,9 & 4,7 & 63,2 & 33,5 & 3,3 & 35,8 & 56,2 & 8,0 \\
\hline $\begin{array}{l}\text { Serv. Aux. da ativ. } \\
\text { Econômica }\end{array}$ & 41,3 & 45,4 & 13,2 & 42,5 & 43,1 & 14,4 & 18,4 & 55,6 & 26,0 \\
\hline Prestação de serviços & 62,6 & 31,7 & 5,7 & 67,5 & 25,4 & 7,1 & 45,4 & 46,3 & 8,3 \\
\hline Social & 39,7 & 50,1 & 10,2 & 45,2 & 43,6 & 11,2 & 19,2 & 58,1 & 22,7 \\
\hline Administração Pública & 36,4 & 50,7 & 12,8 & 44,7 & 43,1 & 12,3 & 22,9 & 58,0 & 19,1 \\
\hline Outras atividades & 32,9 & 53,0 & 14,0 & 32,6 & 51,1 & 16,2 & 15,8 & 61,0 & 23,1 \\
\hline Total & 57,7 & 35,5 & 6,8 & 63,0 & 30,1 & 6,9 & 35,2 & 52,8 & 12,0 \\
\hline
\end{tabular}

Fontes: Censo Demográfico de 1991 (dados amostrais); Laboratório de Estudos

Territoriais (Leste)

Em resumo, dos ocupados em 1991 na fração Norte, aproximadamente 42\% auferiam mais de um salário mínimo. No Nordeste, o quadro era pior, já que nessa mesma situação encontrava-se apenas 37\% da PEA ocupada, enquanto no Centro Sul ocorria o oposto, ou seja a maioria da PEA, cerca de 65\%, auferia mais de um salário mínimo (sendo que quase $53 \%$ dela recebiam entre um e cinco salários mínimos) ${ }^{29}$, revelando portanto uma distribuição bem menos desigual.

\section{Faixas de Renda e Sexo}

A Tabela 5 sintetiza a distribuição da PEA segundo rendimento mensal por fração da rede urbana. Os dados indicam que a distribuição da PEA em três faixas de renda nominal familiar per capita parece ser significativamente diferenciada segundo cada fração da rede. Em outras palavras, a porção Centro Sul afigura-se como a de melhor distribuição da renda per capita, a do Nordeste a pior e a do Norte em situação intermediária. No Nordeste e no Norte a maioria dos ocupados auferia até um salário mínimo em 1991, sendo que a proporção de pessoas em melhor situação em ambas as frações era muito

\footnotetext{
${ }^{29}$ Destes 53\%, cerca de 54\%, o que equivalia a 6.073 .075 de pessoas, auferia entre um e dois salários mínimos. Cadernos do Leste

Artigos Cientificos

Belo Horizonte, Edição Especial, 2000 a 2008
} 
próxima, perto dos 7\%, reforçando, portanto, as evidências de desigualdade de renda expostas na primeira parte desse trabalho.

No Centro Sul, tanto a proporção dos mais bem aquinhoados era substancialmente maior, $12 \%$, quanto era bem maior o 'quantum' de ocupados na faixa intermediária de renda, ultrapassando a metade da PEA, 52,8\%.

\section{Tabela 5}

População economicamente ativa residente em 1991 nas Frações da Rede Urbana, segundo o rendimento nominal familiar per capita

\begin{tabular}{l|rrr}
\hline \multirow{2}{*}{ Faixas de Renda em } & \multicolumn{3}{|c}{ Frações da Rede Urbana } \\
\cline { 2 - 4 } Salários Mínimos & Centro Sul & Nordeste & \multicolumn{1}{c}{ Norte } \\
\hline 0 à 1 & 35,17 & 62,94 & 57,62 \\
1 à 5 & 52,77 & 30,03 & 35,46 \\
Mais de 5 & 12,00 & 6,94 & 6,74 \\
Total $(100 \%)$ & 21.456 .622 & 5.044 .706 & 1.728 .367
\end{tabular}

Fontes: Censo Demográfico de 1991 (dados amostrais); Laboratório de Estudos Territoriais (Leste)

É bem verdade que os níveis de renda aqui mostrados são relativamente baixos, especialmente tendo em conta a capacidade de compra do salário mínimo brasileiro, frequentemente em deterioração, além de variável regionalmente. Contudo, a grande maioria da população brasileira convive ou conviveu, por muito tempo, com situações de pobreza aguda. Tomar valores como múltiplos do salário mínimo em intervalos de classe, sendo o primeiro intervalo indo até um salário mínimo, facilita a comparação e soa razoável, já que se trata de renda familiar individualizada..

Por último, examina-se a desagregação dos dados por faixas de renda e sexo, procurando com isso, introduzir um primeiro olhar sobre a posição de mulheres e homens no mercado de trabalho em cidades importantes da rede urbana brasileira. A participação feminina na dinâmica econômica está, sem dúvida, a exigir maior atenção da teoria econômica contemporânea e de estudos ${ }^{30}$ sócio urbanísticos calcados em evidências empíricas de qualidade, como as disponíveis em nossos censos demográficos.

Os dados da Tabela 6 trazem duas evidências importantes, cada uma delas suscitando variadas questões socioculturais. A primeira refere-se à inserção relativa das mulheres nos mercados de trabalho urbano, por hipótese mais expressiva nas cidades de maior complexidade econômica. A segunda indicaria o status socioeconômico das mulheres diante dos homens, geralmente inferior em termos de renda individual.

\footnotetext{
${ }^{30}$ Estudos que comecem a dar atenção a processos em curso de reestruturação das famílias brasileiras, que, inclusive, indiquem novas tendências de superação de antigos modelos de tamanho e constituição de famílias nucleares de tipo patriarcal.

Cadernos do Leste

Artigos Cientificos

Belo Horizonte, Edição Especial, 2000 a 2008
} 
De fato, os dados confirmam bem a primeira afirmativa, embora a segunda deva ser melhor qualificada.

No Centro Sul e na fração Nordeste, áreas com processos de urbanização mais antigos e bastante consolidados, a ocupação das mulheres ao atingir 36,3\% e 37,5\%, respectivamente, as colocam em posição superior à encontrada na fração Norte, $30,1 \%$ da PEA.

Quanto à renda auferida, os dados indicam que a situação feminina parece melhor no conjunto de cidades da rede urbana brasileira. Na fração Centro Sul verifica-se que há, proporcionalmente, mais mulheres que homens nas faixas intermediárias e superior de renda $(54,0 \%$ e $14,5 \%)$. Nas frações Nordeste e Norte, embora ambos, homens e mulheres estejam mais concentrados na faixa de renda inferior ( 0 a 1 s.m.), as mulheres estão menos concentradas nessa faixa, distribuindo-se melhor entre os três estratos de renda. Além disso, a supremacia feminina na faixa superior de renda per capita é bastante evidente.

Tabela 6

População economicamente ativa residente em 1991 nos municípios das Frações da Rede Urbana, segundo o sexo e rendimento nominal familiar per capita

\begin{tabular}{l|rr|rrr|r}
\hline Faixas de Renda* & \multicolumn{2}{|c|}{ Fração Centro-Sul } & \multicolumn{2}{c|}{ Fração Nordeste } & \multicolumn{2}{c}{ Fração Norte } \\
& Homens & Mulheres & \multicolumn{1}{c}{ Homens } & Mulheres & Homens & Mulheres \\
\hline 0 à 1 & 37,32 & 31,38 & 67,60 & 55,16 & 61,30 & 49,35 \\
1 à 5 & 52,05 & 54,03 & 26,99 & 35,10 & 32,77 & 41,53 \\
Mais de 5 & 10,59 & 14,48 & 5,35 & 9,59 & 5,76 & 8,96 \\
Total $(100 \%)$ & 13678108 & 7778514 & 3152712 & 1891994 & 1196879 & 531488 \\
\hline
\end{tabular}

Fontes: Censo Demográfico de 1991 (dados amostrais); Laboratório de Estudos Territoriais (Leste)

* Faixas de renda segundo salário mínimo vigente em agosto de 1991

Estes resultados podem causar certa surpresa se considerarmos o fato, largamente conhecido, de que em uma mesma atividade, as mulheres são sempre pior remuneradas que os homens. Com os dados censitários é possível lançar mais luz sobre essa discussão?

Inicialmente, cabe observar que o elenco de atividades mal remuneradas e que ocupam muita mão-de-obra contempla principalmente os homens, repercutindo nas proporções da PEA masculina concentradas nas faixas de renda mais baixa. O fato de as mulheres se distribuírem melhor entre as faixas de renda pode ser um corolário desse raciocínio, mesmo que algumas das ocupações remunerem-nas melhor do que os homens. O peso relativo da distribuição feminina entre os setores de atividades é a chave que explica os diferenciais encontrados acima.

Os dados da Tabela 7 elucidam parte destas observações. De fato, as mulheres se concentram principalmente na Prestação de Serviço (onde o emprego doméstico é Cadernos do Leste Artigos Cientificos 
dominante), no Social e no Comércio de Mercadorias. Nas duas primeiras, em todas as frações, a proporção de mulheres é muito maior do que no caso dos homens. No Comércio de Mercadorias, no entanto, as proporções são muito semelhantes.

Não obstante as particularidades regionais, fica evidente que os homens estavam numericamente mais ocupados que as mulheres, distribuídos em um elenco maior de setores de atividade, que, em termos relativos, os remunerava mal, o que fazia as médias de renda baixar em relação as mulheres. Estas, por sua vez, mais concentradas em um número mais restrito de setores, eram também igualmente mal remuneradas, entretanto, a sua expressiva concentração no setor Social as colocava em patamares de remuneração relativamente maior, uma vez que esse setor remunerava melhor que a maioria dos outros, como já se viu anteriormente.

Tabela 7

Distribuição da população economicamente ativa das frações da rede urbana por setores de atividade e sexo - 1991

\begin{tabular}{lrr|rr|r|r}
\hline Setores de Atividade & \multicolumn{2}{|c|}{ Fração Norte } & \multicolumn{2}{r|}{ Fração Nordeste } & \multicolumn{2}{r}{ Fração Centro Sul } \\
\cline { 2 - 8 } & Homens & Mulheres & Homens & Mulheres & Homens & Mulheres \\
\hline Ativ. agrop, ext. veg. e & 22,11 & 4,99 & 9,09 & 2,45 & 3,84 & 1,03 \\
pesca & & & & & & \\
Indústria de transformação & 11,96 & 8,33 & 14,2 & 8,48 & 24,07 & 15,62 \\
$\begin{array}{l}\text { Indústria da construção } \\
\text { civil }\end{array}$ & 9,86 & 0,9 & 12,02 & 1,01 & 11,33 & 1,27 \\
Outras atividades & & & & & & \\
industriais & 4,3 & 1,4 & 2,82 & 1,06 & 2,12 & 0,89 \\
Comércio de mercadorias & 15,92 & 15,51 & 18,8 & 15,7 & 15,39 & 14,65 \\
Transporte e comunicação & 6,49 & 1,47 & 7,04 & 1,23 & 7,78 & 1,76 \\
Serv. Aux. da ativ. & 2,83 & 2,4 & 3,54 & 2,67 & 5,04 & 4,72 \\
econômica & & & & & & \\
Prestação de serviços & 12,21 & 31,57 & 16,29 & 35,27 & 15,57 & 31,72 \\
Social & 4,48 & 23,06 & 5,44 & 23,47 & 4,92 & 19,7 \\
Administração Pública & 7,64 & 7,76 & 7,57 & 5,9 & 5,73 & 3,99 \\
Outras atividades & 2,19 & 2,63 & 3,19 & 2,77 & 4,21 & 4,63 \\
Total & 1.241 .47 & 551.447 & 3.248 .588 & 1.947 .223 & 14.104 .59 & 8.061 .497 \\
& 8 & & & & 6 & \\
\hline
\end{tabular}

Fontes: Censo Demográfico de 1991 (dados amostrais); Laboratório de Estudos Territoriais (Leste)

Enfim, o que os dados estão a sugerir é que a participação das mulheres no mercado de trabalho das áreas urbanas, mesmo que reduzida a setores de atividades específicos, parece contribuir para amenizar a forte desigualdade de renda no interior da PEA e não o contrário, mesmo que em uma mesma atividade as mulheres continuem auferindo salários inferiores aos dos homens. 


\section{1- SÍNTESE E CONCLUSÕES}

O Brasil tornou-se conhecido mundialmente no século XX, especialmente a partir dos anos 50, por várias de suas idiossincrasias de país tropical de grande tamanho geográfico e populacional, multiétnico e com atraentes potencialidades de exploração econômica. Uma característica, bastante conhecida dos brasileiros, que ganhou visibilidade internacional no final do século, refere-se às suas desigualdades econômicas e sociais. Afinal, como entender um país que chegou a ser a oitava economia mundial mas mantendo níveis de desigualdade sociais que o aproximava de países tão pobres quanto os certas regiões da Ásia e da África?

Continua portanto urgente compreender melhor a recorrência destas disparidades visando erradicá-las, mediante políticas públicas mais eficazes que as do passado. Políticas que, inclusive, não ignorem características regionais mais profundas de um país também desigual em termos de vocações territoriais e socioculturais.

Foram várias as tentativas de enxergar melhor o Brasil dividido. Tornou-se usual apontar os contrastes entre os espaços modernos e os atrasados; entre o urbano e o rural; entre as frações meridionais, onde vicejava o desenvolvimento e a riqueza, e as suas opostas, setentrionais, onde mantinham-se o atraso, a pobreza e a miséria. A dualidade impunha-se como ideia força. As comparações com outras regiões do mundo deram sustentação a tese dos “dois Brasis", fazendo surgir o neologismo Belíndia.

A contribuição da geografia na discussão do Brasil dividido vem de longe. Desde as divisões para fins administrativos de fins do século XIX até as divisões voltadas ao planejamento governamental de meados do século XX. As cinco grandes regiões afirmaram-se como divisões oficiais de uso corrente até os dias de hoje, não obstante a proposição recente de Milton Santos que procura ver o país recortado em quatro grandes regiões. Uma outra divisão, entretanto, é conhecida desde fins dos anos 60. A regionalização geoeconômica tripartite de Pinchas Geiger, em face da emergência de Brasília e sua área de influência, apontava para a integração do Centro Oeste com o Sudeste a partir.

O uso de segmentações espaciais em um grande país é um recurso analítico necessário, sobretudo ao se ter em conta que a expansão da complexidade econômica e social não é homogênea. O dado socioespacial e físico geográfico frequentemente estabelece territorialidades duráveis, mesmo considerando a velocidade e o dinamismo da vida de relações. 
Assim ao pensar no País dividido é indispensável não perder de vista suas espacialidades mais notáveis. A recorrência do espaço, e do espaço social em particular, é pré-condição para se estudar, por exemplo, a difusão das redes urbanas em suas conexões inextricáveis com o crescimento econômico-demográfico, com a interiorização da urbanização e com os desenhos, estáveis e instáveis, das regiões brasileiras.

Nesse trabalho procurou-se analisar a rede de localidades urbanas de máxima centralidade, utilizando-se de dados demográficos, que, em alguma medida, introduzissem evidências sobre fluxos migratórios, crescimento populacional, ocupação e renda da PEA. Com isso pôde-se estabelecer uma proposta de rede, cuja consistência encontrou ressonância em trabalhos recentes que trazem o mapeamento de fatos geográficos que articulam a formação territorial em rede, a exemplo das redes de transportes, de bancos públicos e privados, de telefonia e de infraestrutura de engenharia.

A análise dos resultados e a verificação dos interstícios e distâncias espaciais entre os nódulos fizeram surgir um desenho da rede urbana estruturada em três porções, a Centro Sul, a Nordeste e a Norte. Assim, à pergunta sobre as divisões do Brasil, se somos dois, três, quatro ou cinco Brasis, os dados sugerem a divisão em três grandes frações, o que se afigura como uma síntese mais abrangente e atual do Brasil das duas últimas décadas. Utilizando-se portanto de um caminho metodológico próprio, pudemos chegar a um resultado que, em boa medida, coincide com a proposta de Geiger feita a cerca de 30 anos atrás.

De posse dessa divisão e mediante o uso de variáveis censitárias econômicodemográfico, verificou-se a existência de padrões específicos de desigualdade socioespacial entre as três frações. Mesmo que essa metodologia de investigação seja ainda incipiente, os dados não deixam dúvidas: no Centro Sul a desigualdade em termos de renda é relativamente menor e seus residentes convivem com maiores níveis de renda e inserção em atividades econômicas modernas; em situação oposta, o Nordeste padece da pior condição, baixos níveis de remuneração no interior da PEA ocupada, predominantemente em atividades de tipo tradicional. Não é surpresa constatar que alguns setores distribuíamse sintomaticamente entre as frações, tipificando-as, em boa medida, como a indústria de transformação no Centro Sul, as atividades agropecuárias e extrativistas no Norte e as atividades tradicionais no Nordeste.

Por último, os dados mostraram a inserção diferenciada das mulheres nos mercados de trabalho das 165 áreas urbanas da rede aqui apresentada, trazendo à reflexão a questão da contribuição das mulheres na redução das desigualdades de renda no interior da PEA, Cadernos do Leste 
mesmo que menos inseridas no trabalho que os homens e participando em ocupações relativamente específicas. 


\section{REFERÊNCIAS BIBLIOGRÁFICAS}

AMARANTE, Luis A., BONDIOLI, Paulo. A apropriação regional da renda nacional no Brasil; 1975-85. São Paulo em Perspectiva, revista da fundação SEADE, São Paulo, v.1, n.3, out/dez, 1987.

ANDRADE, T.A e SERRA, RV. O recente desempenho das cidades médias no crescimento populacional urbano brasileiro. IPEA. (Texto para discussão 554). 1998.

ANDRADE, T.A. e LODDER, C.A. Sistema urbano e cidades média no Brasil.

IPEA/INPES, Rio de Janeiro, 1979AMARANTE, Luis A., BONDIOLI, Paulo. A apropriação regional da renda nacional no Brasil; 1975-85. São Paulo em Perspectiva, Revista da Fundação SEADE, São Paulo, v.1, n.3, out/dez, 1987.

AZZONI, Carlos R. Indústria e reversão da polarização no Brasil, São Paulo, IPE/USP, 1986.

BADIE, Bertrand. O fim dos territórios; ensaio sobre a desordem internacional e sobre a utilidade social do respeito. Instituto Piaget. 1996

BAENINGER, Rosana. Homogeneização de tendências populacionais em São Paulo: o papel dos Pólos Regionais no processo de urbanização e de redistribuição espacial da população. In: IX ENCONTRO NACIONAL DE ESTUDOS POPULACIONAIS DA

ASSOCIAÇÃO BRASILEIRA DE ESTUDOS POPULACIONAIS, 9, 1994, Caxambú. Anais... Belo Horizonte, 1994. p.473-498.

BAENINGER, Rosana. Deslocamentos populacionais, urbanização e regionalização. REVISTA BRASILEIRA DE ESTUDOS POPULACIONAIS, Brasília, v.15 - n.2, p.6782, jul./dez. 1998.

- A nova configuração urbana no Brasil; desaceleração metropolitana e redistribuição da população. In: XI ENCONTRO NACIONAL DE ESTUDOS POPULACIONAIS. Caxambu. ABEP. 1998

Movimentos migratórios no contexto paulista; tendências da década de 80. In: X ENCONTRO NACIONAL DE ESTUDOS POPULACIONAIS. Caxambu. ABEP. 1996

BALAN, Jorge. Migrações e desenvolvimento capitalista no Brasil: ensaio de interpretação histótico-comparativa. Estudos CEBRAP, V.5, p. 5-79, jul/set. 1973.

BOGUS, L. M. M. et al. Processos migratórios no Estado de São Paulo. In: VII ENCONTRO NACIONAL DE ESTUDOS POPULACIONAIS, Caxambu. Anais do VII Encontro. 1990. São Paulo: ABEP, 1990, (V.1).

BOYD, M. Family and Personal Networks in International Migration: recent developments and new agendas, in INTERNATIONAL MIGRATION REVIEW, 198923 (3): 638-670.

BOURDIEU, Pierre. Coisas ditas. São Paulo. Brasileiense, 1990. 
BRAMAEKER, F. E. J. Os centros urbanos: 1950 a1980. REVISTA BRASILEIRA DE ESTATÍSTICA., ano XLVII. N 180, jul-set 1986, p. 279-303.

BREMAEKER, F.E.J. Implicações dos movimentos migratórios nos municípios no período 1980-1991. Anais do VII Encontro Nacional de Estudos Populacionais, São Paulo, ABEP, vol.3, 1992, pp. 213-29.

BRITO,F. População, espaço e economia numa perspectiva histórica: o caso brasileiro. Belo Horizonte: UFMG/CEDEPLAR, 1997 (Tese de doutorado em demografia).

BRITO, Fausto. Minas e o nordeste: perspectivas migratórias dos dois grandes reservatórios de força de trabalho. In: II ENCONTRO NACIONAL SOBRE MIGRAÇÃO. Ouro Preto. ABEP. 1999

BRITO, Fausto e VAINER, Carlos. Migration and Migrants Shaping Contemporary Braazil. XXIV GENERAL POPULATION CONFERENCE, Salvador, aug, 2001 (meio digital).

PERROUX, Françoise. A economia do século XX. Lisboa. Herder, 1967.

CANO, Wilson. Desequilibrios regionais e concentração industrial no Brasil;1930-1970. Rio de Janeiro: Global, 1985.

CARVALHO, J.A.M. e MACHADO, C.C. Quesitos sobre migrações no Censo Demográfico de 1991. REVISTA BRASILEIRA DE ESTUDOS POPULACIONAIS, 9(1), 1992.

CARVALHO, J.A.M. Migrações internas; mensuração direta e indireta.REVISTA BRASILEIRA DE ESTATISTICA, 43 (171): 549-83, JUL/SET, 1982.

CARVALHO, J.A.M e RIGOTTI, J.I. Os dados censitários brasileiros sobre migrações internas; algumas sugestões para análise. In: XI ENCONTRO NACIONAL DE ESTUDOS POPULACIONAIS. Caxambu. ABEP. 1998

CARVALHO, J.A.M., et al. Migrações internas; mensuração direta e indireta.VIII Seminários sobre a economia mineira, BDMG, BEMGE, UFMG, Diamantina, 1998, 397 420.

CEDEPLAR, Belo Horizonte. Economia regional, sistema urbano e processo migratório na região polarizada por Belo Horizonte; estudos de base para definição de estratégias alternativas de sistemas urbanos no Brasil. Belo Horizonte: 1979, 329 p.

CHRISTALLER, W. Die Zentralen Orte in Süddenstschland, Iena, Gustav Fischer, 1933 (tradução americana de C.W. Baskin), Central Place in Southern Germany, N. Jersey, Prentice-Hall, 1966.

CORDEIRO, H.K. e BOVO, D.A. A modernidade do espaço brasileiro através da rede nacional de telex. In: Revista Brasileira de Geografia, 52 (1), jan-mar, 1990, p. 107-155

CORREAA, Roberto L. Interações espaciais. In: CASTRO, I.E., GOMES, P.C.C e

Cadernos do Leste

Artigos Cientificos

Belo Horizonte, Edição Especial, 2000 a 2008 
CORRÊA, P.L. Explorações geográficas. Bertrand Brasil. Rio de Janeiro, 1997a.

CORRÊA, Roberto L. Os estudos de redes urbanas no Brasil até 1965. SIMPÓSIO DE GEOGRAFIA URBANA. Instituto Panamericano de Geografia e História, Rio de Janeiro, 1968, p. 173-206.

CORRÊA, Roberto L. Trajetórias geográficas. Rio de Janeiro, Bertrand Brasil, 1997b.

COSTA, M.A. Urbanização e migração urbana no Brasil. Rio de Janeiro. IPEA/INPES, 1975, Monografia n. 21.

CUNHA, J. M. P. Migração intrametropolitana em São Paulo: características de um fenômeno multiface. In: VII ENCONTRO NACIONAL DE ESTUDOS POPULACIONAIS, Caxambu. Anais do VII Encontro (v.1), 1990. São Paulo: ABEP, 1990, (v.1), p. 489-519.

J.M.P. Mobilidade populacional e expansão urbana; o caso da região metropolitana de São Paulo. 1994. Tese (doutorado). UNICAMP.

CUNHA, J.M.P e BAENINGER, R. A migração nos estados brasileiros no período recente; principais tendências e mudanças. In: II ENCONTRO NACIONAL SOBRE MIGRAÇÃO. Ouro Preto. ABEP. 1999

COSTA, R.H. e GOMES, P.C.C.. "O espaço na modernidade”. In: TERRA LIVRE; O espaço em questão. AGPl/Marco Zero, São Paulo, 1988.

DEGENNE, Alan e FORSÉ, Michael. Introducing Social Networks. London: SAGE Publications, 1999.

DELLA DONE, M. "Teorias sobre a cidade". São Paulo, Martins Fontes, 1983.

DAVIDOVICH, F., BUARQUE DE LIMA, O.M. (1975). Contribuição ao estudo de aglomerações urbanas no Brasil, REVISTA BRASILEIRA DE GEOGRAFIA, ano 37, n. 1, jan/mar, 1975 , p. $50-82$.

DAVIDOVICH, F. (1989). Tendência da urbanização no Brasil, uma análise espacial. IN: REVISTA BRASILEIRA DE GEOGRAFIA, ano 37, v. 51, n. 1, jan/mar, 1989.

DEFFONTAINES, P. Como se constituiu no Brasil a rede de cidades. In: Boletim geográfico 14, 1944 e Boletim Geográfico 15, 1944.

DIAS, Leila C. Redes eletrônicas e novas dinâmicas do território brasileiro. In: Brasil; questões atuais da reorganização do território, org. por CASTRO, I.E., GOMES e CORRÊA, P.L. Rio de Janeiro, Bertrand Brasil, 1996.

DIAS, Leila C. Redes: Emergência e Organização. In: Geografia: Conceitos e Temas, org. por CASTRO, I.E., GOMES e CORRÊA, P.L. Rio de Janeiro, Bertrand Brasil, 1995).

DINIZ, C.C. Desenvolvimento poligonal no Brasil; nem desconcentração, nem contínua polarização. Belo Horizonte, NOVA ECONOMIA (Revista do Departamento de Ciências Econômicas da UFMG). V.31. N.11. Set. p. 35-64. 1993.

Cadernos do Leste

Artigos Cientificos

Belo Horizonte, Edição Especial, 2000 a 2008 
FAISSOL, S. O espaço, território, sociedade e desenvolvimento brasileiro. In: FUNDAÇÃO INSTITUTO BRASILEIRO DE GEOGRAFIA - IBGE, Rio de Janeiro, 1994.

FAISSOL, Speridião. Migrações internas no Brasil e suas consequências no crescimento urbano e desenvolvimento econômico. Revista Brasileira de Geografia. v.36, n.2, p.3-102. abr/jun. 1973.

FARIA, Vilmar. Desenvolvimento, urbanização e mudanças na estrutura do emprego: a experiência brasileira dos últimos trinta anos". In: SORJ, B., ALMEIDA, M. (Org.). Sociedade e política no Brasil pós-64. São Paulo, Brasiliense, 1983.

FARIA, Vilmar. O sistema urbano brasileiro; um resumo das características e tendências recentes. Estudos CEBRAP, São Paulo, n.18, p. 91-115, 1976.

FRANCISCONE, J.G. e SOUZA, M.A.A. A política nacional de desenvolvimento urbano; estudos e proposições alternativas. Brasília, IPEA/ILAN, 1976.

FRIEDMAN, J. Planejamento regional: problema de integração espacial. In: SCHWARTZMAN, J. (org). Economia Regional; textos escolhidos. CEDEPLAR/CETREDE-MINTER, 1977.

FRIEDMANN, J. e WEAVER, C. "Territorio Y Funcion", Madrid, Nuevo Urbanismo, 1983.

GEIGER, Pedro P. Evolução da rede urbana brasileira. Instituto Nacional de Estudos Pedagógicos (Ministério da Educação e Cultura). Rio de Janeiro. 1963. 464p.

GEIGER, Pedro P. Exemplos de hierarquia de cidades no Brasil. BOLETIM CARIOCA DE GEOGRAFIA. Rio de Janeiro. N3-4.V10.5-17. 1957.

GOLDSTEIN, Sidney. Facets of redistribution; reseach challenges and opportunities. Demography, Washington, v.13, n.4, p. 423-434, Nov, 1976.

HAESBAERT, Rogério. Des-territorialização e identidade; a rede "gaucha" no nordeste. Niterói. Eduff. 1997.

HADDAD, Paulo. Economia Regional; teorias e métodos de análise. Fortaleza: Banco do Nordeste do Brasil, 1989.

HIRSCHMAN, A.O. The strategy of economic development. New Haven: Conn. Yale University Press, 1958,217p.

IBGE (FUNDAÇÃO INSTITUTO BRASILEIRO DE GEOGRAFIA E ESTATÍSTICA). Divisão do Brasil em regiões funcionais urbanas. Rio de Janeiro, 1972.

IBGE, Rio de Janeiro. Regiões de influência das cidades. Rio de Janeiro, (co-patrocínio do Ministério da Habitação e Urbanismo), 1987.

IBGE. Divisão regional do Brasil em mesorregiões e microrregiões geográficas. Rio de Janeiro. 1992.

Cadernos do Leste

Artigos Cientificos

Belo Horizonte, Edição Especial, 2000 a 2008 
IBGE. Indicadores Sociais; regiões metropolitanas, aglomerações urbanas, municípios com mais de 100000 habitantes.MASSENA, R.M.Rosa. (org.) Rio de Janeiro. IBGE. Departamento de Estatística e Indicadores Sociais, 1988.

IBGE. Regiões de influências das cidades, Revisão atualizada do estudo Divisão do Brasil em Regiões Funcionais Urbanas. IBGE, Rio de Janeiro, 1987. 183p.

IPEA. Relatório Final do Estudo Caracterização e Tendências da Rede Urbana do Brasil. Brasília.1999.

JACOBS, Jane. "Morte e vida de grandes cidades”. Martins Fontes. São Paulo, 2001.

JANNUZZI, Paulo de M. A mobilidade social dos migrantes no contexto da crise e instabilidade dos anos 80 em São Paulo. In: II ENCONTRO NACIONAL SOBRE MIGRAÇÃO. Ouro Preto. ABEP. 1999

KATZMAN, Martin T. Urbanização no Brasil a partir de 1945. In: BACHA, E., KLEIN, H. S. A transição incompleta; Brasil desde 1945. Rio de Janeiro: Paz e Terra, 1986, p.177-229.

LAMBERT, Jacques. Os dois Brasis. São Paulo. Companhia Editora Nacional.1967

LINN, J.F. Cities in the developing word; policies for their equitable and efficient growth, New York. Oxford University Press, 1983.

. Tendencias de la urbanización, inversión de la polarización y politica espacial en colombia. In: BOISIER, S. et al. Experiencias de planificación regional en America Latina. Santiago del Chile, ILPES/SIAP, 1981.

LOPES, Juarez B. e PATARRA, Neide L Redistribuição regional e rural-urbana da população brasileira. São Paulo. CEBRAP, 1974, Cadernos CEBRAP, 20.

MACHADO, C.C., HAKKERT, R. Uma análise exploratória da informação sobre a migração inter e intramunicipal no Censo Demográfico de 1980. REVISTA BRASILEIRA DE POPULAÇÃO, São Paulo, v.5, p1-2-, jul/dez, 1988

MARTINE, G. et al. A urbanização no Brasil: retrospectiva, componentes e perspectivas. In: PARA a década de 90; prioridades e perspectivas de políticas públicas. Brasília: IPEA/IPLAM, 1990.

MARTINE, G. Adaptação de migrantes ou sobrevivência dos mais fortes? Brasília, PNUD, 1976. In: MOURA, A.M. ed., Migração interna; textos selecionados, Fortaleza, 1980.

MARTINE, G., DINIZ, C.C. Economic and demographic concentration in Brazil: recent inversion of historiacal patterns. Liege: IUSSP, 1989, mimeo.

MASSEY, Douglas S. et al. Theories of international migration: a review and appraisal. POPULATION AND DEVELOPMENT REVIEW, v. 1, n. 1, set. 1993.

MATA, Milton et al. Migrações internas no Brasil; aspectos econômicos e demográficos. Rio de Janeiro, IPEA/INPES, 1973.

Cadernos do Leste

Artigos Científicos

Belo Horizonte, Edição Especial, 2000 a 2008 
MATOS, R.E.S. Dinâmica migratória e desconcentração da população na macrorregião de Belo Horizonte. Belo Horizonte. CEDEPLAR (tese de doutorado), 1995.

Questões teóricas acerca dos processos de concentração e desconcentração da população no espaço. In: REVISTA BRASILEIRA DE ESTUDOS POPULACIONAIS. São Paulo, 1995, p. 35-58.

Ralfo. Desconcentração espacial e processos de exclusão da população migrante em Belo Horizonte. Rio Claro, GEOGRAFIA, v. 21, n.1, p. 153-173, 1996.

Crescimento populacional e migração interna nos principais municípios de Minas Gerais. ANAIS DO I ENCONTRO NACIONAL SOBRE MIGRAÇÃO. Curitiba, 1997, p. 329-348.

Migração e desconcentração demográfica nas principais áreas de atração populacional de Minas Gerais. ANAIS DO XI ENCONTRO NACIONAL DE ESTUDOS POPULACIONAIS. Caxambu, 1998, p. 713-728.

Distribuição e dispersão populacional em Minas Gerais no período 1981/91. In: II ENCONTRO NACIONAL SOBRE MIGRAÇÕES, 1999, Ouro Preto. Belo Horizonte: ABEP/GT Migração-CEDEPLAR/UFMG, 1999.

Aglomerações urbanas, rede de cidades e desconcentração demográfica no Brasil. XII Encontro Nacional de Estudos Populacionais. Caxambu, out., ABEP, 2000.

MATOS, Ralfo e BAENINGER, Rosana. Migration and urbanization in Brazil: process of spatial concentration and deconcentration and the recent debate. XXIV GENERAL POPULATION CONFERENCE, Salvador, aug, 2001 (meio digital).

MATOS, Ralfo e SANTOS, Ivan, S.M.S. Movimentos migratórios e difusão de pobreza nas microrregiões geográficas. XII ENCONTRO NACIONAL DE ESTUDOS POPULACIONAIS. Caxambu, 2000 (anais em meio digital).

MATOS, Ralfo e FERREIRA, Rodrigo N. Inserção ocupacional de emigrantes das áreas metropolitanas de São Paulo e Rio de Janeiro. (aceito para publicação nos anais do XIII Encontro Nacional de Estudos Populacionais em nov. de 2002)

MATOS, Ralfo e BRAGA, Fernando G. Rede urbana e redistribuição espacial da população brasileira (aceito para publicação nos anais do XIII Encontro Nacional de Estudos Populacionais em nov. de 2002)

MONBEIG, P. Aspectos geográficos do crescimento de São Paulo. Boletim Geográfico. Rio de Janeiro. 1954, n12. V119 p 144-147.

MONBEIG, P. Pionniers et planteurs de São Paulo. Paris, Armand Colin, 1952, 376p.

MOTTA, Diana M. e AJARA, Cesar. "Rede urbana brasileira-hierarquia das cidades". Curso de Gestão Urbana e de Cidade EG/FJP-WBI-PBH-ESAF-IPEA, ago, 1999

MYRDAL, Gunnar. Economic theory and under-developed regions. London, Gerald Duckworth, 1957. 167p.

Cadernos do Leste

Artigos Cientificos

Belo Horizonte, Edição Especial, 2000 a 2008 
NACIONES UNIDAS. Métodos de medición de la migración interna. Manual VI. Nueva York, 1972.

NEGRI, Barjas. Concentração e desconcentração industrial em São Paulo (1880-1990). Campinas SP, Editora da Unicamp, 1996.

NUNES COELHO, A.L. et. al. A reversão do comportamento migratório mineiro: um desafio ao planejamento. Fundação JP: análise e conjuntura, Belo Horizonte, v. 12, n. 3/4, p. 46-88, mar/abr, 1982.

NUNES COELHO, Alzira L. et al. O poder de atração e fixação de migrantes em cidades de porte médio. In: ENCONTRO NACIONAL DE ESTUDOS POPULACIONAIS, 5, 1986. Aguas de São Pedro. Anais ... São Paulo, ABEP, 1986, v.2, p. 699-723.

PANARAS, N.L. \& CUNHA, J.M.P. Migração; um tema complexo. In: São Paulo em perspectiva. Revista da Fundação SEADE. v.1, n.2, jul/set 1987

PIORE, Michael. Birds of passage: migrant labor and industrial societies. New York: Cambridge University Press, 1979.

RANDOLPH, Rainer. Modernização e rede urbana; tendências das transformações nos Sudeste brasileiro na década de 70. In: METROPOLIZAÇÃO e rede urbana, org. por RIBEIRO, A.C.T. e MACHADO, D.B.P., IPPUR/UFRJ, set, 1990.

REDWOOD III, John. Reversion de polarizacion, ciudades secundarias y eficiencia en el desarrollo nacional: una vision teorica aplicada al Brasil contemporaneo.Revista lationoamericana de estudios urbanos regionales, Santiago: v. 11, n.32, dez. 1984.

RIBEIRO, J.T.L. Estimativas da migração de retorno e de alguns de seus efeitos demográficos indiretos no Nordeste brasileiro. 1970/1980 e 1981/1991. Belo Horizonte:UFMG/CEDEPLAR, 1997 (Tese de doutorado em demografia).

RIBEIRO, J.T.L., CARVALHO, J.A.M., WONG, L.R. Efeitos demográficos da migração de retorno; uma proposta metodológica. In: X ENCONTRO NACIONAL DE ESTUDOS POPULACIONAIS DA ASSOCIAÇÃO BRASILEIRA DE ESTUDOS POPULACIONAIS, 1996, Caxambú. Anais... Belo Horizonte, 1996. p. 955-972.

RICHARDSON, Harry W. Polarization reversal in developing countries. The Regional Science Association Papers, Los Angeles, v. 45, nov, 1980.

RIGOTTI, J.I. Fluxos migratórios e distribuição espacial da população na região metropolitana de Belo Horizonte -década de 70. Belo Horizonte, 1994, 109 p. Dissertação (mestrado). CEDEPLAR/FACE/UFMG.

RIGOT'TI, J.I. Técnicas de mensuração das migrações, a partir de dados censitários: aplicação aos casos de Minas Gerais e São Paulo. Belo Horizonte, MG, CEDEPLAR/UFMG, (Tese de doutorado), 1999.

SALES, Tereza. Migrações inter-regionais nos anos 80; a não política para os excluídos. São Paulo em Perspectiva, v., n.3, p.57-59, jul/ set, 1984.

Cadernos do Leste

Artigos Cientificos

Belo Horizonte, Edição Especial, 2000 a 2008 
SALIM, Celso Amorin. Estrutura agrária e dinâmica migratória na região Centro-Oeste, 1970-80: análise do êxodo rural e da mobilidade da força de trabalho no contexto de industrialização da agricultura e da fronteira urbanizada. Belo Horizonte. 1992. Tese (doutorado) CEDEPLAR/FACE/UFMG. 365 p.

SANTOS, Milton. A urbanização brasileira. Hucitec. São Paulo. 1993.

SAWYER, Donald R. Fluxo e refluxo da fronteira agrícola no Brasil; ensaio de interpretação estrutural e espacial. Revista Brasileira de Estudos Populacionais. 1(1/2):3-33, jan/des.1984.

SAWYER Donald e RIGOT'TI, J. Irineu. Migration and Spatial Distribution of Rural Population in Brazil, 1950-2050. XXIV GENERAL POPULATION CONFERENCE, Salvador, aug, 2001 (meio digital).

SERRA, R.V. Desconcentração urbana e oportunidades de trabalho: um estudo da integração dos imigrantes no mercado de trabalho das cidades médias. In: CNPD - I e II Concurso Nacional de Monografias sobre População e Desenvolvimento, Brasília, 1999.

SILVA, Lea M. Pesquisa de fluxos migratórios para Belo Horizonte. In: CEDEPLAR Migrações internas e desenvolvimento regional. Belo Horizonte, 1973.

SINGER, Paul. Migrações internas: considerações teóricas sobre seu estudo, in: Economia Política da Urbanização, São Paulo, Brasiliense, 1976.

SOUZA, Maria A.A. O novo Brasil urbano: integração ou fragmentação? In: GONÇALVES, M.F. O novo Brasil urbano. Mercado Aberto. Porto Alegre, 1995.

TILLY, Charles. Transplanted Networks. In: YANS-MC LAUGHLIN, Virgínia (ed.), Immigration Reconsidered, NY, Oxford, Oxfor University Press, 1990, p. 79-95.

TOWNROE, P. M. e KEEN, D. Polarization reversal in the state of São Paulo. Regional Studies, v. 18, p. 45-54, 1984. 